2 norden 



\section{Kunskap för grön tillväxt}

Delrapport 1 om de nordiska ländernas IKT-politik

Annelie Helmersdotter Eriksson och Lars Häggmark

(Sweco Eurofutures) 
Kunskap för grön tillväxt

Delrapport 1 om de nordiska ländernas IKT-politik

TemaNord 2011:553

ISBN 978-92-893-2255-3

(C) Nordiska ministerrådet, Köpenhamn 2011

Denna rapport är utgiven av med finansiellt stöd från Nordiska ministerrådet. Innehållet i rapporten avspeglar inte nödvändigtvis Nordiska ministerrådets synpunkter, åsikter eller anbefallningar.

www.norden.org/publikationer

\section{Det nordiska samarbetet}

Det nordiska samarbetet är ett av världens mest omfattande regionala samarbeten. Det omfattar Danmark, Finland, Island, Norge och Sverige samt Färöarna, Grönland och Åland.

Det nordiska samarbetet är politiskt, ekonomiskt och kulturellt förankrat och är en viktig partner i europeiskt och internationellt samarbete. Den nordiska gemenskapen arbetar för ett starkt Norden i ett starkt Europa.

Det nordiska samarbetet vill styrka nordiska och regionala intressen och värderingar i en global omvärld. Gemensamma värderingar länderna emellan bidrar till att stärka Nordens ställning som en av världens mest innovativa och konkurrenskraftiga regioner.

\section{Nordiska ministerrådet}

Ved Stranden 18

DK-1061 Köpenhamn K

Telefon (+45) 33960200

www.norden.org 


\section{Innehåll}

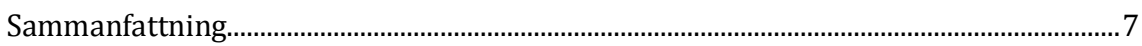

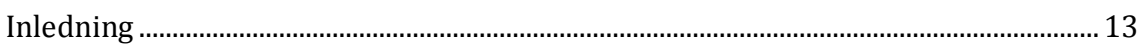

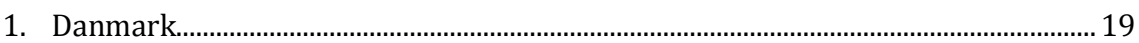

1.1 Aktörer och inriktning .................................................................................... 19

1.2 Några viktiga områden för Danmark inom IKT ............................................... 21

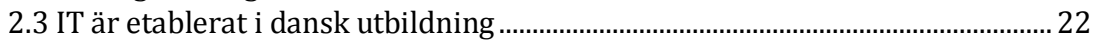

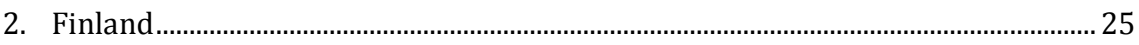

$2.1 \quad$ Aktörer och inriktning .................................................................................. 25

2.2 Några viktiga områden för Finland inom IKT .................................................... 26

2.3 IT har en plats i finsk utbildning, delvis med grön inriktning....................... 28

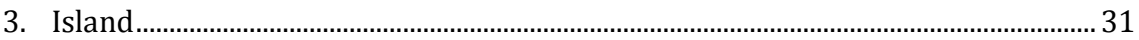

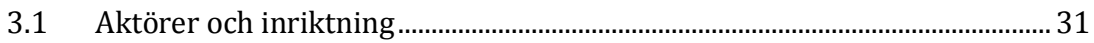

3.2 Några viktiga områden för Island inom IKT ..................................................... 32

3.3 Infrastrukturen för IKT är på plats i isländsk utbildning................................. 33

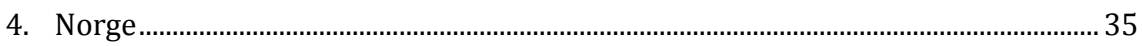

$4.1 \quad$ Aktörer och inriktning ................................................................................. 35

4.2 Några viktiga områden för Norge inom IKT ………......................................... 36

4.3 Sporadisk användning av IKT i utbildning ...................................................... 37

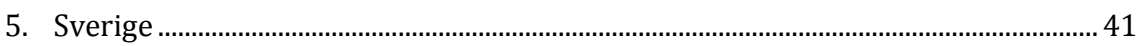

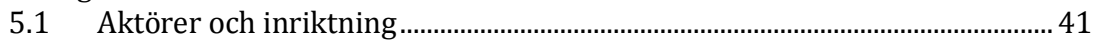

5.2 Några viktiga områden för Sverige inom IKT ................................................... 44

5.3 IKT används i forskning och utbildning .............................................................. 45

6. Avslutande tankar och reflektioner ........................................................................ 49

6.1 IKT för grön tillväxt ....................................................................................... 49

6.2 Digital kompetens som grund i samhället.................................................... 51

6.3 Förbättring av strukturer kan göras gemensamt .......................................... 52

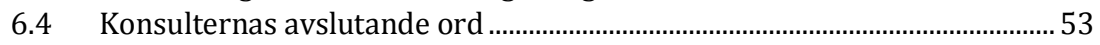





\section{Sammanfattning}

Informations- och kommunikationsteknologi (IKT) genomsyrar i stort sett hela samhället och har därför stor påverkan på hälsa och miljö. IT/IKT ses som en viktig förutsättning för grön tillväxt och har påverkan på själva IT-branschen i sig likaväl som på energi, olika former av tjänster för både medborgare och näringsliv, offentliga myndigheters information och tjänster, telekom och kommunikation etc.

De största vinsterna för miljömässigt och ekonomiskt för användning av IKT anses vara inom energigenerering och produktion, byggnader och transporter - tre områden som bidrar till den största delen av utsläpp av växthusgaser. De nordiska länderna är alla involverade, mer eller mindre, i utveckling av dessa områden.

Frågan om hur IKT kan användas på ett bra och smart sätt berör hela Norden liksom stora delar av världen, och ger avtryck i strategier och insatser om än i olika grad och omfattning. Många av frågorna är generiska för de nordiska länderna och inriktningen är inte alltför tydlig $\mathrm{i}$ deras politik. Exempel på en fråga som länderna arbetar med, utöver de som ovan nämnts, i olika omfattning är digital kompetens hos befolkningen. Myndigheternas omställning till digitala tjänster är ett annat område. Standardisering är ett tredje område.

Det finns olika nordiska samarbeten och gemensamma strategier idag som har bäring på IT/IKT-politiken. Exempelvis kan nämnas strategin eScience, the Nordic Data Grid facility, NORDUnet etc.

En grund för högre användning av IT och IKT och därmed en grönare tillväxt, är att den digitala kompentensen höjs i samhället. D v s den ITkunskap som behövs för att kunna ta del av och påverka informationssamhället. Att inte behärska modern teknik kan skapa klyftor med återverkning på såväl utbildningssystem som samhälle.

Vad gör de nordiska länderna inom IT-politiken som bidrar till grön tillväxt? Då IT ingår i princip allt som ryms i våra samhällen idag, har denna rapport velat belysa vad de nordiska länderna gör på området dels på en allmän nivå och speciellt vad gäller utbildningssystemen i Danmark, Finland, Island, Norge och Sverige. Digital kompetens kan många gånger stärkas i utbildningen, om än den troligen inte startar där.

\section{Danmark}

Danmark anses ligga i den absoluta framkanten när det gäller "digital economy" och har efter Sverige den högsta andelen av Internet, mobiltelefoner, e-business etc. Att landet ligger långt fram visar sig också i att 
många världsledande företag vill förlägga FoU-insatser till framför allt Köpenhamnsområdet för att skaffa sig ett fotfäste i regionen.

De politiska ambitionerna är många gånger ambitiösa. Politik och program koordineras centralt där bl.a. digitalisering sätts i ett tillväxtperspektiv. Insatsområdena fokuseras på bredband, energi, transporter, standardisering, den digitala ekonomin samt den digitala förmågan. Danmark arbetar också inom t.ex. OECD för att föra upp frågan om grön IT.

I högre utbildning och inom forskning pågår en hel del initiativ. När det gäller grund- och gymnasieskola så tycks det finnas förbättringsutrymmen då IT på inget sätt är fullt integrerat i undervisningen, trots satsningar på pedagogisk användning av IT i skolan samt att tillgång till datorer och Internet i skolan är god. Tekniskt stöd och support för lärare har efterfrågats och initiativ har efter detta tagits för att öka ITmognaden hos lärare samt att tydliggöra undervisningsmål med tydlig hänvisning till e-lärande.

\section{Finland}

Liksom i övriga Norden är klimatet gynnsamt för e-business och andra Internetbaserade möjligheter. Individer och näringslivet använder också digitala varor och tjänster i hög grad. Finland deltar inom Nordic Foresight tillsammans med Sverige, Norge och Danmark där strategier och scenarios utarbetas för användning av grön IT inom olika samhällsområden. Inom Grön IKT har betydande utveckling och forskning bedrivits i Finland, och betydande insatser görs inom näringspolitiken för att främja grön IKT.

Finland kallas "världens testlaboratorium" för telekommunikation och nya teknologier och tjänster testas ofta här. Energi (-effektivitet och -besparing), bygg och transport är sektorer där åtgärder utpekas som viktiga. Under det finska ordförandeskapet i Nordiska ministerrådet har klimatförändringarna valts som tema, ett tema som förutsätter en effektiv användning av IKT.

Det finns en nationell plan för hur IKT ska användas i undervisningen. Planen börjar användas våren 2011. Det är viktigt ur ett samhällsomvandlingsperspektiv att IKT genomsyrar kommande generationers kunskaper och arbetssätt. Det finns dock betydande skillnader mellan finska skolor och hur IT används samt mängden och standarden på utrustning, som är eftersatt på många håll.

\section{Island}

Island har ett gott renommé vad gäller kunskap inom IKT. Statlig styrning och koordinering av IT har funnits sedan 1990-talet. Då departementet för utbildning, forskning och vetenskap även publicerade sitt första policydokument rörande informationssamhället. Därefter har flera politiska styrdokument och visioner lagts fram. 
Grön IT har här en direkt koppling till de gröna energikällorna som finns på Island. Den geografiska placeringen gör också att landet ligger bra till för att fungera som "hub" mellan Nordamerika och Europa vilket också har börjat ta sig konkreta uttryck i företag och tjänster. Transport, energi, kommunikation och dataöverföring är områden som står i fokus i Islands strategi för 2020.

Det pågår forskning och insatser för IT i utbildning i Island. Skolor är ofta väl utrustade när det gäller datorer och support. Vidareutbildningen för lärare anses också vara god. IT tycks trots detta inte vara integrerat i undervisningen.

\section{Norge}

Oljebranschen sägs ha drivit den teknologiska utvecklingen med ITlösningar i Norge och det krävs där, liksom i andra länder, arbetskraft med högteknologiskt kunnande. Ett område norsk IKT-politik riktar in sig på är värdeskapandet av offentliga data. Genom att öka tillgängligheten och förbättra nyttjandet vill regeringen öka marknadspotentialen såväl som offentlig effektivitet. Energi, transport och logistiksystem, nya elektroniska tjänster, bredband är andra områden som ses som betydelsefulla för en hållbar utveckling.

Studier visar på allmänt god IT-kunskap i skolan, men också på sporadisk användning av IKT i undervisningen trots satsningar. Strukturella hinder som tid, organiseringen i klassrummen samt lärarnas vidareutbildning nämns som hinder.

\section{Sverige}

Sverige placerar sig jämte Danmark i topp i rankingen av "digital economy". Fokus ligger i hög grad på att realisera de potentialer och möjligheter som finns idag. Näringslivets arbete med att på allvar göra affärer av IT och miljö ligger i startgroparna. Liksom övriga nordiska länder ses byggnader/fastigheter, energi, transport, logistik och digitalisering $\mathrm{i}$ samhället som angelägna områden.

Flertalet universitet/högskolor har tagit upp forskning och utbildning som betydande miljöaspekt. När det gäller digital kompetens i skolundervisningen anses Sverige inte ha kommit så långt som många andra länder när det gäller att integrera digital kompetens i skola, vuxenutbildning och i lärarutbildning. Det saknas också tydliga politiska och centrala styrdokument för grön IT i skolan, något som på sikt riskerar att hämma en snabb samhällsomvandling i grön riktning med bibehållen ekonomisk tillväxt. 


\section{Avslutande ord}

Vi ser sammanfattningsvis följande punkter som viktiga att arbeta vidare med på nordisk nivå:

- Tvärsektoriella FoU-satsningar. Då tillämpningen av IKT ser olika ut inom olika branscher och sektorer, kan det finnas skäl att främja lärande mellan olika områden. Tvärsektoriella FoU-satsningar kan vara ett sätt att främja både lärande och innovativa lösningar. Befintliga nordiska organisationer kan driva detta arbete

- Tvärvetenskapliga forskningsprogram där IKT är inkluderat. Tydlig finansiering av forskningsprogram som inkluderar t.ex. miljö och IKT behövs för att utforska nya möjligheter och nya fördelar i användningen av IKT för ett bättre klimat och en hållbar utveckling. Eventuellt kan Nordforsk spela en roll här

- Eventuellt kan även forskningsfinansiering behöva inriktas på att belysa effekterna av IKT på systemnivå. Det kan handla om förväntade och oväntade effekter av IKT:s bidrag till miljömål, hur det främjar förnybara energikällor, minskar transportvolymer, optimerar hushållsförbrukning av el etc.

- Standardisering, interoperabilitet, datakompabilitet etc. gagnas av att samarbete sker på nordisk nivå. Bl.a. kan NICe utnyttjas i ännu högre grad, som nordisk think tank och pådrivare. NICe har tidigare engagerat sig för ökad standardisering. De nordiska länderna ligger långt fram i IT-mognad och IKT-kunskap och kan därmed påverka och vara med och driva även den globala utvecklingen på området

- Öka den digitala kompetensen i hela Norden som en bas för grön tillväxt, genom gemensamma satsningar på information såväl som skol- och utbildningssamarbeten. Information från Nordiska Ministerrådet eller någon av dess institutioner kan spridas genom befintliga kanaler som Journal of Nordregio (till tjänstemän och forskare), Nordens Tidning m.fl.

- Ge goda exempel och inspiration till lärare att arbeta mer med IKT. Här finns inspiration att finna från enskilda nordiska länder. Om olika officiella nordiska organ och/eller exempelvis Föreningen Norden eller liknande organisationer som finns representerade över hela Norden fick ett sådant uppdrag, skulle de kunna tjäna som tillhandahållare av seminarier, information etc. för att förmedla både goda exempel och kunnande på olika håll i de olika nordiska skolsystemen

- Olika nordiska organ som NiCe, NordForsk m.fl. kan ges uppdrag att öppna upp för kunskapsutbyte och samverkan genom att - i än högre grad än idag - rikta inbjudningar till seminarier etc. på temat

- Arrangera nordiska informationssatsningar, inom ramen för det nordiska IT-forum som är etablerat, som riktar sig mot företag och innovationssatsningar inom IT/IKT om grön tillväxt i syfte att samla diskussioner och skapa input till nordisk policy 
- Kartläggningar och konkreta policyförslag rörande t.ex. lärarutbildningen kan bli resultatet av samordnade nordiska utredningsinitiativ. Det kan även handla om större fokus i olika stöd och mobilitetsprogram för att främja utbyte av kunskaper inom exempelvis IT-användning i undervisningen

Våra samhällen är beroende av IKT för att fungera och just därför är behovet av en väl genomtänkt och utformad IT-politik stort. Utvecklingen går dock oerhört snabbt inom IT/IKT och ju mer input som kan införskaffas, t.ex. genom arbetsgrupper inom det nordiska samarbetet, desto större chans att få en träffsäker bild vid skapandet av gemensamma policys och satsningar. 



\section{Inledning}

\section{Informations- och kommunikationsteknologins betydelse}

Informations- och kommunikationsteknologi (IKT) genomsyrar i stort sett hela samhället och har därför stor påverkan på hälsa och miljö. Studier visar t.ex. att IKT-branschen har lika högt utsläpp av klimatpåverkande $\mathrm{CO}_{2}$ som flygtrafiken. ${ }^{1}$ Bedömare menar dock att IKT-branschen kanske måste få stå för en viss mängd utsläpp för att samhället ska minska utsläppen totalt sett. ${ }^{2}$

Dessutom ses en effektiv användning av IKT som en förutsättning för en fortsatt tillväxt och framför allt grön tillväxt. En effektiv digital kommunikation ger positiva effekter på klimatet genom att påverka exempelvis resmönster och logistiklösningar i en klimatvänligare riktning. Alla företag och hushåll bör därför ha möjlighet att kommunicera digitalt utan begränsningar i tid och rum. För detta kan det behövas en offensiv strategi för att utveckla digital kommunikation i samhället.

Många, däribland OECD, ser de största vinsterna för smartare miljömässiga lösningar vara inom energiproduktion och distribution, byggnader och transporter - tre områden som bidrar till den största delen av utsläpp av växthusgaser, och inom vilka IT kan bidra till smartare och mer miljömässiga lösningar. ${ }^{3}$

Det talas också om grön IT - ett vidsträckt begrepp men har i vissa sammanhang definierats som "forskning om och användning av IT på ett effektivt och miljövänligt sätt". Intresset för grön IT är stort, i Norden liksom i övriga världen. Antalet träffar på Google på "Green IT" har mångdubblats bara från 2008 till 2011. Grön IT är omfattande, samtidigt som själva begreppet är vagt och odefinierat enligt bedömare. ${ }^{4}$

\footnotetext{
${ }^{1}$ http://www.gartner.com/it/page.jsp?id=503867

2 "Med it kan vi klara klimatet", Computer Sweden, 2009-03-27.

${ }^{3}$ Greener and Smarter ICTs, the Environment and Climate Change, 2010, OECD.

${ }^{4}$ http://www.naturvardsverket.se/upload/06_produkter_och_avfall/produktion_konsumtion/miljoledning /dokumentation/gron_it/gron_it_hakan_nordin.ppt
} 


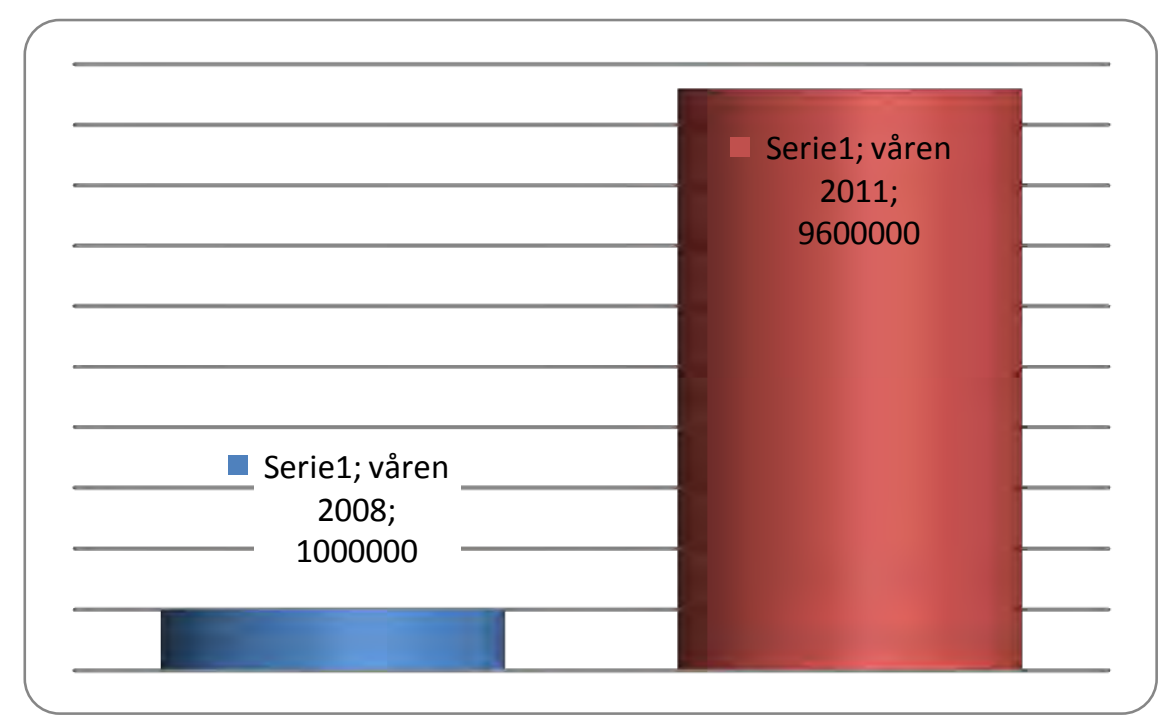

Figur 1: Antal träffar på Google på "Green IT" år 2008 respektive 2011.

Inom IT och telekom-världen har arbetet fokuserats på energianvändning och minskning av det ekologiska fotavtrycket av hårdvara. Givet den påverkan som energianvändning har på vårt samhälle ter sig detta som ett naturligt fokus, även om grön tillväxt givetvis handlar om mer än så. ${ }^{5}$ Exempelvis är frågan om "smart grid" - intelligenta elnät - med tvåvägskommunikation och möjlighet till lokal produktion, en fråga som upptar en stor del av IKT- och energipolitiken. Smarta elnät öppnar möjligheter för att optimera produktion och användning. Länder som Tyskland och Italien har varit tidigt ute med teknologin och USA:s president understryker nödvändigheten av detta "paradigmskifte" på väg mot en grönare ekonomi. En annan fråga som är aktuell är exempelvis den att omvandla produkter till tjänster, s.k. cloud computing. ${ }^{6}$ Detta är en fråga som berör alla de nordiska länderna, om än i olika grad.

Just för att våra samhällen är beroende av IKT för att fungera är behovet av en väl genomtänkt och utformad IT-politik stort. Det finns dock bedömare som pekar på att det inte är möjligt att formulera en generell politik i dag. I stället måste politiken anpassas till olika sektorer. ${ }^{7}$ En viktig omständighet att bära i minnet är också att teknikanvändningen inte är en lättstyrd process. Det är en process som styrs av brukare och producentintressen snarare än av politiken. Tekniken används ofta på helt andra sätt än vad den skapats för och som kunnat förutses.

Från flera håll understryks IT/IKTs betydelse för klimatproblematiken och nödvändigheten av uthållighet i vårt sätt att leva och använda

\footnotetext{
5 Beyond Power Consumption: What It Really Means to Go Green, 2009, IDC.

${ }^{6}$ Det innebär i korthet att den egna datorn inte innehåller mjukvara utan att dessa produkter köps som tjänster via nätet. Det kan röra applikationer, tillgång till filservrar, e-post, databaser etc.

${ }^{7}$ http://computersweden.idg.se/2.2683/1.333556/sverige-behover-hallbar-it-politik
} 
resurser. IDC har beräknat att fram till år 2020 kommer IT att ha besparat världen 5,8 gigaton $\mathrm{CO}_{2}$. IDC utvecklar detta: "IT-industrin ansvarar också för en del av $\mathrm{CO}_{2}$-utläpp, men IT är en del av lösningen då det är den motor som skapar innovation inom alla sektorer. Informationsoch kommunikationsteknologi har en enorm effekt på alla branscher." IDC menar också utifrån sina beräkningar, att användning av IT och telekom i ett slag kan sänka $\mathrm{CO}_{2}$-utläppen med $25 \%$ i världens 20 rikaste länder. ${ }^{8}$

IT och telekom är inslag i EU:s strategi som ses som viktiga för att få fart på tillväxten och ta itu med framtidsfrågor som klimatet och den åldrande befolkningen. ${ }^{9}$ EU har antagit en strategi, The Digital Agenda, för ett digitaliserat Europa år 2020.10 The Digital Agenda är ett av de sju flaggskeppsinitiativ inom Europa 2020 Strategy och har som övergripande syfte att sporra innovation och ekonomisk tillväxt. Här talas om övergången från informationssamhället till ett digitalt och kunskapsbaserat samhälle. ${ }^{11}$ EU:s digitala agenda avspeglar sig även i de nationella strategierna i Norden, oavsett EU-medlemskap eller ej, där ländernas regeringar plockar upp huvudspåren för att omsätta dem till nationella insatser.

Norden anses ligga i framkant när det gäller att använda IKT som en "hävstång" för ekonomiskt tillväxt. En av orsakerna bakom de framskjutna positionerna är att Norden har innovationsvänliga miljöer tillsammans med hög utbildningsnivå och branschnära forskning. ${ }^{12}$

På Nordisk nivå har utbildnings- och forskningsministrar enats om en nordisk "eScience"-strategi där de nordiska länderna samarbetar. ${ }^{13}$ Här spelar IKT huvudrollen då det handlar om att utveckla avancerade verktyg med hjälp av informations- och kommunikationsteknologin för att använda i forskning och experiment.

Nordiska ämbetsmannakommittén för utbildning och forskning har ett IT-politiskt forum med nordiska berörda departementschefer som har ansvar för koordinering av nationell IT-politik, i syfte att förankra den nordiska IT-politiken på nationell nivå. Här kan erfarenhetsutbyte ske kring prioriteringar samt konkreta nationella initiativ. ${ }^{14}$

Energi är ett område som samtliga nordiska länder arbetar mycket med. På gemensam nivå ger exempelvis Nordisk Energiforskning bidrag till forskningsprojekt i programmet "Sustainable Energy Systems, 2050" där projekten inriktas på tvärvetenskapliga samarbeten inom t.ex. sol-

\footnotetext{
8 http://www.computerworld.dk/art/54256/her-er-verdens-groenneste-itland? $\mathrm{a}=$ related $\& \mathrm{i}=54261 \&$ bottom

${ }^{9} \mathrm{http}: / /$ ec.europa.eu/information_society/digital-agenda/index_en.htm

10 Europe 2020 sets out a vision to achieve high levels of employment, a low carbon economy, productivity and social cohesion

11 http://eur-lex.europa.eu/LexUriServ/LexUriServ.do?uri=CELEX:52010DC0245R(01):EN:NOT

12 The Global Information Technology Report 2010-2011, 2011, World Economic Forum.

13 http://www.nordforsk.org/no/news/escience-ar-framtiden. E-science eller e-vetenskap är utvecklandet av nya arbetsformer och forskningsmetoder i elektronisk infrastruktur med hantering av stora mängder digital data.

${ }^{14}$ http://www.norden.org/sv/om-samarbetet/samarbetsomraaden/informationsteknik
} 
kraft, bioenergi, vindkraft, smarta elnät, policy projekt och transport. 15 De nordiska länderna Danmark, Finland, Norge och Sverige samarbetar även i The Nordic Data Grid Facility, NDGF. Sammanslutningen ska underlätta för forskare i dessa länder att skapa och delta i omfattande och stora "computational challenges" som är svårt för enskilda nationella forskargrupper att klara av. ${ }^{16}$

På utbildningsområdet sker samverkan utifrån IT/IKT-perspektiv t.ex. I NORDUnet, som är ett samarbete mellan de fem nordiska nationella forsknings- och utbildningsnätverken (Forskningsnettet i Danmark, Funet i Finland, RHnet i Island, Uninett i Norge samt SUNET i Sverige). Ambitionen är att verka som ett nordiskt och internationellt nätverk och tillhandahålla e-infrastrukturtjänster för forskarsamhället och utbildningssystemet i Norden. ${ }^{17}$

På skolans område är en given fråga synen på digital kompetens, d v s den IT-kunskap som behövs för att kunna ta del av och påverka informationssamhället. I grund och botten ses det som en teknisk färdighet men inbegriper även ett förståelse- och attitydbegrepp. Ämnet är aktuellt och det tas nationella initiativ och skrivs om ämnet.18 I många EUländer har arbetet kommit långt med att integrera digital kompetens $\mathrm{i}$ både skola, vuxenutbildning och i lärarutbildning.

OECD pekar på en klyfta mellan de som kan och de som inte kan nyttja modern teknik, vilket kan både i dag och i framtiden vara ett allvarligt hot mot både utbildningssystemen och samhällsutvecklingen. ${ }^{19}$

\section{Vårt uppdrag och tillvägagångssätt}

Sweco Eurofutures har i ett större övergripande uppdrag analyserat hur utbildnings-, forsknings- och innovationspolitiken kan bidra till grön tillväxt i de fem nordiska länderna (se rapporten Kunskap för grön tillväxt, maj 2011). Önskan att titta närmare på vad de nordiska ländernas IT-politik bidrar med till grön tillväxt, har tillkommit under huvuduppdragets gång. Detta är redovisningen av detta deluppdrag.

Fokus har här varit vad de nordiska länderna gör inom olika delar av IT-politiken som bidrar till grön tillväxt. I detta uppdrag har vi försökt kartlägga strategier och ge goda exempel på utvecklingsinsatser inom IT där grön tillväxt är ett drivande syfte.

Utöver en mer generell och ämnesövergripande redogörelse har vi under varje landsvis redovisning ett avsnitt om IT i utbildningen. Individers kompetensbehov i informationssamhället behöver tillgodoses och

\footnotetext{
15 http://www.nordicenergy.net/section.cfm?id=1-0\&path=220)

16 http://www.ndgf.org/ndgfweb/nordic_e-science.html

17 http://www.nordu.net/ndnweb/home.html

18 Exempelvis Digital kompetens i undervisningen, 2010, Ulf Jämterud

19 http://www.oecd.org/document/31/0,3746,en_2649_35845581_38358154_1_1_1_1,00.html
} 
där kan skola och utbildning, om än inte enbart de, spela en viktig roll. Bl.a. EU:s digitala strategi påpekar behovet av att digitalisera samhället och där barn och unga måste få med sig en sådan kompentens från sina skolår. Att lägga grunden för framtida medborgare i skola och utbildning är också viktigt ur ett samhällsomvandlingsperspektiv.

Tillvägagångssättet har varit att samla och analysera dokument från ländernas departement och centrala myndigheter, t.ex. nationella ITstrategier (i förekommande fall), forskningsanalyser, program- (eller insats-/projektdokument) information, IT/IKT-branschens egna sammanslutningar och deras strategier etc. Vi har även intervjuat några få personer per land, utöver de som även intervjuats i samband med den ovan nämnda studien om grön tillväxt.

I rapporten används inte bara begreppet IT (informationsteknologi) utan även det bredare begreppet IKT (informations- och kommunikationsteknologi).

\section{Rapportens disposition}

I detta första kapitel ges en inledning och bakgrund (avsnitt 1.1). Vi redogör också för fokus i vårt uppdrag samt tillvägagångssätt (1.2).

Kapitel 2-6 redogör för de fem nordiska ländernas läge vad gäller IT/IKT och vad den nationella IT-politiken tycks vara inriktad på. Vi redovisar också några exempel på nordisk samverkan inom området.

Kapitel 7 slutligen, ger en sammanfattande bild och analys.

I bilaga redogörs även för de viktiga källor vi använt. 



\section{Danmark}

\subsection{Aktörer och inriktning}

I sin tillväxtstrategi poängterar regeringen bl.a. att "Danmark skal være et grønt bæredygtigt samfund og blandt verdens tre mest energieffektive lande". ${ }^{20}$ Danmark har den högsta andelen av Internet, mobiltelefoner och e-business implementering i Europa. Regeringens har exempelvis satt som mål att alla danskar ska ha tillgång till bredband 2010.21 De spenderar också mest på IT per capita i världen. Detta ses sammantaget som en tydlig indikation på att Danmark ligger i den absoluta framkanten när det gäller IT och rankas som nummer två när det gäller "digital economy ranking" 22 och som nummer sju i The Global Information Technology Report. ${ }^{23}$

Köpenhamn som del av Öresundsregionen är det största IT-klustret i Danmark. Där finns ett antal snabbt växande sektorer och branscher. Detta kluster består av mer än 100000 IT-anställda. Alla stora internationella IT-företag har förlagt FoU-aktiviteter inom IT här för att skaffa sig ett starkare fotfäste i regionen. ${ }^{24}$

I Danmark koordineras politik och program på IT-området centralt. Ministeriet för vetenskap, teknologi och innovation ansvarar för utveckling av såväl politik som infrastruktur. ${ }^{25}$ Ministeriet har bl.a. ett arbetsprogram där digitalisering sätts i tillväxtperspektiv. Där fokuseras insatsområdena på bredband, på innehåll och den digitala ekonomin samt på digital förmåga. ${ }^{26}$

Det finns även en s.k. digitaliseringsstrategi för den offentliga sektorn för att öka användningen av digitala tjänster för näringsliv och medborgare. ${ }^{27}$ Tillsammans med regionala och lokala myndigheter har den danska regeringen nyligen skrivit fram en ny nationell strategi för digitalisering av den offentliga sektorn 2011-2015.28 Den danska genomsnitt-

\footnotetext{
20 Danmark 2020 - Viden > vækst > velstand > velfærd, 2010, Danmarks regering.

21 IT and Telecommunications Policy Report, 2009, The Danish government.

22 Digital economy rankings 2010. Beyond e-readiness, Economist Intelligence Unit. En benchmarking av hur IKT påverkar ett lands ekonomiska och sociala utveckling. Benchmarkingen görs genom att mäta drygt 100 kvalitativa och kvantitativa faktorer för att kunna ranka länder utifrån kvaliteten av infrastruktur för IKT, användarnas, företagens och staternas förmåga att använda IKT på ett effektivt och förd elaktigt sätt. 23 The Global Information Technology Report 2010-2011, 2011, World Economic Forum 24 http://www.finfacts.com/irelandbusinessnews/publish/printer_1000article_10009918.sht.ml ${ }^{25} \mathrm{http} / / / \mathrm{vtu} . \mathrm{dk} /$ it-og-telekommunikation

26 Digitale veje til vækst - Videnskabsministeriets digitale arbejdsprogram, 2010, Videnskabsministeriet. ${ }^{27}$ Strategi for digitalisering af den offentlige sektor 2007-2010 - Mod bedre digital service, øget effektivisering og stærkere samarbejde, 2007, Danmarks regering. 
liga statliga myndigheten är ganska liten och upplever utmaningar med att hantera IKT. Bedömare menar att det behövs kompetenslyft och ser ett behov av gemensamma metoder samt bättre samarbete mellan leverantörer och rådgivare till den offentliga sektorn. ${ }^{29}$ Även om det återstår både utmaningar och arbete för att möta dem, anses Danmark ligga i framkant när det handlar om att använda online-tjänster och att arbeta för en mer IT-effektiv offentlig sektor. ${ }^{30}$

Våren 2010 genomfördes en tillväxtkonferens med fokus på digitalisering där både politiker och representanter från näringsliv deltog. Där underströks bl.a. att digitalisering av den offentliga sektorn är ett avgörande steg för ett effektivt framtida samhälle. ${ }^{31}$

Den statliga myndigheten IT- og Telestyrelsen genomför regeringens politik på området. Utöver det konkreta arbetet med den nationella strategin, fungerar myndigheten som ett kunskapscentrum som samlar in och sprider erfarenhet inom t.ex. e-förvaltning som liksom i andra nordiska länder bedöms vara en angelägen fråga. En av nyckelfrågorna handlar om standardisering för att underlätta interoperabilitet, d.v.s. säkra att olika IT-system kan tala med varandra. ${ }^{32}$ Fr.o.m. 2010 finns också myndigheten Videncenter for grøn it, vars uppgift är att främja användningen av grön IT hos myndigheter, näringsliv och individer. Där definieras grön IT som följande: "Grøn it er energieffektiv og miljørigtig anvendelse af informations- og kommunikationsteknologi. Grøn it handler både om at reducere miljøbelastningen fra selve it-udstyret og om at reducere miljøbelastningen på andre områder ved hjælp af it." ${ }^{33}$

Insatser sker exempelvis genom Rådet for Teknologi og Innovation (RTI). Rådet ska stärka framtida tillväxt och innovation i näringslivet genom teknologiska och innovationspolitiska initiativ. Ett sådant initiativ är Grön IKT i programmet Strategiske vækstteknologier. ${ }^{34}$

I mitten 1990-talet inrättades Teknologirådet under Videnskabsministeriet, ett oberoende rådgivande organ med uppgift att följa den globala tekniska utvecklingen och analysera vad den innebär för olika samhällsområden. Rådets främsta uppgift är att förmedla sina resultat till regering och folketing samt att främja den allmänna teknikdebatten i Danmark. Bland Teknikrådets projekt syns både miljö/klimat- och ITaspekter (bl.a. i skolan). ${ }^{35}$ Det finns även ett IKT-råd med uppgift att främja en långsiktig strategi- och policyutveckling inom IKT-området

mn-2\&p_p_col_count=2\&_homeBlog_WAR_in safeportlet_action=detail\&_homeBlog_WAR_insafeportlet_article Id $=189946 \&$

29 Professionalisering af arbejdet med statslige it-projekter i Danmark, 2010, presentation av Finansministeriet vid norska Difi.

30 http://www.regjeringen.no/nb/dep/fad/tema/ikt-politikk/ikt-politikken.html?id=630885http://

www.oecd.org/document/41/0,3746,en_33873108_33873309_45382505_1_1_1_1,00.html

31 http://www.itb.dk/site.aspx?p=18\&nid=1875

32 http://www.itst.dk/

33 http://www.itst.dk/groenit/om-videncenter-for-groen-it-1/kommissorium

${ }^{34} \mathrm{http} / / /$ www.fi.dk/raad-og-udvalg/raadet-for-teknologi-og-innovation

35 http://www.tekno.dk 
samt arbeta för att IKT står högt på den politiska agendan. Rådets medlemmar består av individer från både privat och offentlig sektor. ${ }^{36}$

Danmark arbetar också internationellt, t.ex. i samarbete med OECD, med att stärka och att föra upp frågan om exempelvis grön IT. ${ }^{37}$ Andra exempel är att Danmark stått värd för en OECD-konferens om användningen av IKT som bidrag till bättre miljö och klimat. ${ }^{38}$ Intervjupersoner i andra nordiska länder pekar också på att Danmark är aktiv i det internationella arbetet och har spelat en stor roll i skapandet av fora och dokument inom EU vad gäller olika IT-frågor etc.

\subsection{Några viktiga områden för Danmark inom IKT}

Energi är en fråga som globalt ses som en av de viktigaste utmaningarna de närmaste åren, dels att producera energi på ett hållbart sätt och att använda energi på ett smartare sätt. Frågan om energi och energieffektivitet är givetvis på agendan såväl i Danmark som resten av Norden. Danmark har arbetat fram en energistrategi, Energistrategi 2050, för att kunna göra samhället fritt från fossila bränslen. ${ }^{39}$ Forskning och utvecklingsarbete pågår med intelligenta elnät, "Eco grid", intelligenta byggnader, utveckling av teknologier som vindkraft, solceller, ellagring etc. där IKT spelar en avgörande roll. ${ }^{40}$

Transporter är ett annat område. Det handlar om såväl person- som godstransporter där frågor som bränsle, laddstolpar till elbilar, standardisering av teknologi etc. är betydelsefulla. Dessa typer av frågor kräver dock tid för att utvecklas och kunna implementeras varför det på kort sikt under innevarande årtionde framförallt handlar om effektivisering och minskat oljeanvändning i transportsektorn. ${ }^{41}$

Standardisering, som tidigare nämnts (se avsnitt 2.1), är en fråga som också ges utrymme och ses som viktig att arbeta med.

För att uppnå grön tillväxt i samhället krävs ökat fokus på intelligenta lösningar i alla sektorer i samhället för att uppnå reduktion av CO2utsläpp såväl som energieffektiva lösningar. I Danmarks "digitala arbetsprogram" fokuseras följande: Bredband, den digitala ekonomin samt tillgänglighet och användning av IKT. ${ }^{42}$

Bredband är en förutsättning för en effektiv användning och ger ramarna för tillväxt. Här finns ett mål om utbyggnad av bredband i landet (se

\footnotetext{
36 http://ikt-raadet.dk/

$37 \mathrm{http}: / /$ www.itst.dk/groenit/om-videncenter-for-groen-it-1/groen-it-internationalt

$38 \mathrm{http}$ ///www.itst.dk/groenit/om-videncenter-for-groen-it-1/groen-it-internationalt/oecd-konference-maj2009? searchterm=oecd $\% 0$ A $\% 20 \% 20 \% 20 \% 20 \% 20 \% 20 \% 20 \% 20 \% 20 \% 20 \% 20 \% 20 \% 20 \% 20 \%$ 20\%20\%20\%20\%20\%20\%20konference\%20gr\%C3\%B8n\%20it

39 Energistrategi 2050, 2011, Danmarks Regering.

40 http://www.ens.dk/da-dk/Sider/forside.aspx

${ }^{41}$ Energistrategi 2050, 2011, Danmarks Regering.

42 Digitale veje til vækst - Videnskabsministeriets digitale arbejdsprogram, 2010, Ministeriet for Videnskab, Teknologi og Udvikling.
} 
avsnittet 2.1 ovan). Säkerhet är en annan grundsten som kräver kontinuerliga insatser.

Den digitala ekonomin handlar om bl.a. om digital självbetjäning på både offentliga och privata tjänster, detta är ett ämne som Danmark arbetar med liksom de övriga nordiska länderna. Bredband, både tillgång till och hastighet på, har också stor betydelse för utbredning av Cloud computing, vilket räknas kunna ge bättre utnyttjande av resurser då det används mindre energi men även omgärdas av mindre kostnader för investering etc. Här genomförs utvecklingsprojekt, juridiska ramar och säkerhet ses över etc. I den digitala ekonomin inryms även att i ökad utsträckning nyttja befintlig teknik som exempelvis videokonferenser för minskat resande. Då tekniken redan har funnits i flera år handlar det mer om motivation och beteendepåverkan. 43

Danmark ser även behovet av mer forskning inom IKT-området för att vara konkurrenskraftiga och finna fler och smarta användningsområden för IKT i samhället. Nära förknippat med forskning är också innovation för användningen av IKT som behöver främjas, t.ex. har verktyg för att underlätta privatpersoners energiförbrukning tagits fram. ${ }^{44}$

Det tredje området är kunskap och motivation att använda IKT bland medborgare, företag, offentliga instanser $\mathrm{m}$ fl. IKT-användning blir alltmer oavhängig av tekniska plattformar och därmed behöver kompetensinsatser täcka in mer medier än datorer. ${ }^{45}$

\subsection{IT är etablerat i dansk utbildning}

Skolan och utbildningssystemet spelar en viktig roll i att lägga grunden för kunskap att använda IKT. IT i skolan tycks vara väl etablerat i Danmark. Danska grundskolelärare ligger på andra plats i Europa när det gäller att använda datorer i undervisningen: år 2006 använde $96 \%$ av lärarna i den danska grundskolan datorer i undervisningen, det var fem elever per dator och i stort sett alla datorer i skolan hade tillgång till internet (97 \%). Trots att både kännedom om och tillgång till IT finns bland lärarna är inte IT en integrerad del av undervisningen. ${ }^{46}$

När det gäller IT i grundskola och gymnasium har stora satsningar på pedagogisk IT-användning (ca en miljard DKK sedan mitten av 90-talet) gjorts, bl.a. genom de båda stora satsningarna IT, medier og folkeskolen samt IT i folkeskolen. En stor del av satsningarna har rört hårdvara och infrastruktur, men satsningar har även gjorts på kompetensutveckling och utveckling av digitala lärarresurser. Trots dessa satsningar har undersökningar visat att användningen av de digitala möjligheterna inte

\footnotetext{
${ }^{43}$ Ibid.

${ }^{44}$ Ibid.

$45 \mathrm{Ibid}$.

${ }^{46} \mathrm{http}: / /$ www.tekno.dk/subpage.php3?article=1720\&survey=8
} 
sker i så stor skala, och traditionella läromedel, tryckta eller fotokopierade, dominerar fortfarande i undervisningen ${ }^{47}$ Utvärderingar pekade också på behovet av tekniskt stöd och support för lärarna. ${ }^{48}$ Som svar på detta tog Undervisningsministeriet initiativ som riktades på att skapa större IT-mognad hos lärare samt skrev fram undervisningsmål med tydlig hänvisning till s.k. e-læring.

I undervisningsmålen, Fælles Mål 2009, finns ett flertal kunskapsmål som rör IT och digitala medier och som knyter an till den pågående samhällsutvecklingen. Målen pekar på vikten av att IT används på sätt som både skapar nya vägar för undervisningen och utvecklar elevernas lärande inom viktiga områden. ${ }^{49}$

Teknologirådet konstaterar att den digitala infrastrukturen till stor del är på plats ute på skolorna, tack vare tidigare satsningar. Men för att den pedagogiska IT-användningen i skolan ska ge ett bra stöd åt elevernas lärande och kunskapsutveckling krävs en flexibel, öppen och lättanvänd infrastruktur som främjar samarbete inom och utanför skolan. Rapporten pekar på betydelsen av att skolorna satsar på lösningar som minskar plattformsberoende och undanröjer svårigheter och hinder. Rapporten rekommenderar också politiker att reflektera över en rad frågor som rör framtida tjänsteutbud för lärare och skolor. ${ }^{50}$

IT genomsyrar som redan nämnts, hela vårt samhälle och har betydelse för utveckling inom alla områden. IT handlar inte bara om kodning utan rör i högre grad att skapa lösningar för människors och samhällets behov. IT-utbildningar inom Danmarks universitet samverkar och har en gemensam site för att ge överblick över vilka utbildningar som finns på området. Där ses både humanistiska, samhällsvetenskapliga och naturvetenskapliga IT-utbildningar. ${ }^{51}$

Det pågår en del hel forskning på området IT. Bl.a. IT-universitetet $\mathrm{i}$ Köpenhamn som har en tvärvetenskapligt perspektiv på både utbildning och forskning inom IT. ${ }^{22}$ Ett annat exempel är DTU:s där IKT tillhör universitetets högprofilområden inom forskning och de aviserar att de tänker avsätta extra resurser till dessa högprofilområden. Flera andra av forskningsområdena är naturligt nog beroende av IT på många sätt. ${ }^{53}$

\footnotetext{
${ }^{47}$ Digitale laringsressourcer i folkeskolen og de gymnasiale ungdomsuddannelser, 2009, DREAM och Laremiddel.dk.

${ }^{48}$ It i skolen, 2009, Danmarks Evalueringsinstitut.

${ }^{49}$ http://www.uvm.dk/Uddannelse/Folkeskolen/Fag\%20proever\%20og\%20evaluering/

Faelles\%20Maal\%202009.aspx

50 Skole og medier - it-understøttelse af læring, 2011, Teknologirådet.

51 http://www.futurepeople.dk/

52 http://www.itu.dk/

53 http://www.dtu.dk
} 



\section{Finland}

\subsection{Aktörer och inriktning}

Finland kommer på 4:e plats i rankingen av "influence of ICT in economic (and social) progress". T o m år 2009 mättes istället "e-readiness", och då låg landet på 10:e plats. ${ }^{54}$ I The Global Information Technology Report 2010-2011 rankas Finland på tredje plats. ${ }^{55}$ Liksom i övriga Norden innebär det ett relativt gynnsamt klimat för e-business och allmänt goda Internetbaserade möjligheter samt en hög grad av individers och näringslivets användning av digitala varor och tjänster.

Klimatförändringen och energislöseriet anses kräva snabba åtgärder. Grön IT skapar ny affärsverksamhet och möjliggör ny praxis och nya processer. Finland anses ha goda utvecklingsmöjligheter, och inte minst Tekes har på olika sätt engagerat sig i att stödja IT-användandet, och det med gröna förtecken. ${ }^{56}$ Informations- och kommunikationstekniken spelar en viktig roll i lösningar som skapar hållbar utveckling, energieffektivitet och affärsverksamhet. Produkter, tjänster och affärsverksamhet som sparar miljön (cleantech) är den snabbast växande branschen både i Finland och i övriga världen och också den som intresserar investerarna mest. Det anses viktigt inte minst genom att EU har förbundit sig till att främja energieffektivitet och att minska koldioxidutsläppen avsevärt, med hjälp av informations- och kommunikationsteknik, till år 2020.

Redan år 2007 samverkade finska VTT med svenska FOI, danska DTI och norska SINTEF (inom Nordic Foresight) kring vad som kallades Futures of the ICT environment and applications on the Nordic level. ${ }^{57}$ Där diskuterades bl.a. scenarios och strategier för användning av Grön IT på olika samhällsområden, bl.a. gjordes landvisa SWOT-analyser. Bilden är att informations- och kommunikationsteknologi kan utnyttjas mer för att utveckla välfärden i de nordiska länderna. För Finlands del fann utredarna en tydlig fokusering på teknisk/teknologiska initiativ och politikutveckling, medan den sociala sidan var mer framträdande i de övriga deltagande länderna.

I samband med den ekonomiska recessionen började ubikvitär eller ubik (ubiquitous = överallt närvarande) IT uppmärksammas mer i Finland. ${ }^{58}$ Det är en viktig utvecklingstrend inom informations- och kom-

\footnotetext{
54 http://graphics.eiu.com/upload/EIU_Digital_economy_rankings_2010_FINAL_WEB.pdf 55 The Global Information Technology Report 2010-2011, 2011, World Economic Forum

56http://www.tekes.fi/sv/community/Nyheter/478/Nyhet/1334?name=Miljosparande+affarsverksamhet ${ }^{57}$ http://www.vtt.fi/inf/pdf/publications/2007/P653.pdf

58http://www.tekes.fi/sv/community/M\%C3\%A5nadens_\%C3\%B6versikter/665/M\%C3\%A5nadens_\%C3 \%B6versikten/1592?name=Ubik+it+ny+framgangshistoria+for+Finland
} 
munikationstekniken som får betydelse på många samhällsområden, däribland skolan och forskningen. Tanken är att tekniken ska fungera obemärkt som hjälp för människan. Det handlar om olika slags datoriserade hjälpmedel för både vardagen och arbetslivet. En utredning över programvarubranschen har nyligen visat på ett stort behov av att öka forskningen kring "ubika" program och utvecklingsmetoder.

Också den privata sektorns aktörer uppmärksammar IT-sektorn och de gröna aspekterna. Även om den ekonomiska recessionen gick hårt åt företagen inom IKT-branschen bedrevs flera projekt för utveckling och strategi under 2010. Tillväxten förväntas öka under det innevarande året. Med stöd av bl.a. Tekes har betydande utveckling och forskning bedrivits, inte minst på området Grön IKT.

Tekes s.k. GIGA-program ${ }^{59}$ (konvergerande nätverk) som avslutades i mars 2011 inriktades på utveckling av trådlöst bredband med tillhörande affärsverksamhet. Resultatet blev ny företagsverksamhet, betydelsefulla resultat i forskningsprojekten samt internationella öppningar. Det är fortfarande oklart vilken betydelse detta kan få inom forskningsoch utbildningssektorn.

\subsection{Några viktiga områden för Finland inom IKT}

Vikten av IKT-sektorns utveckling i Finland visas bl.a. av dokumentet "Ett produktivt och nyskapande Finland - Digital agenda för åren 2011-2020", som riksdagen godkände i början av 2011. I redogörelsen fastställs centrala mål för det finländska informationssamhället under de kommande åren och åtgärder som krävs för att nå dem. Bl.a. betonas vikten av att ta $\mathrm{i}$ bruk nya teknologier i avsikt att främja en hållbar utveckling.

Det är av intresse att Finland ibland kallas för världens testlaboratorium när det gäller telekommunikation. Nya tjänster och teknologier testas ofta på ett tidigt stadium i landet, som också används för försökslansering av stora tillverkare som Siemens och Hewlett Packard. Antalet anställda i IKT-sektorn i Finland har gradvis stigit och är nu uppe i ca 120000 . Av över 3000 företag i den berörda företagssektorn är flera av betydande omfattning.

I Statsrådets framtidsredogörelse om klimat- och energipolitiken 60 från 2009 behandlas vägen till ett utsläppssnålt Finland. De åtgärder som förutses bygger i hög grad på användningen av IT och IKT. Det handlar t.ex. om förbättrad energieffektivitet och energibesparing inom ett flertal sektorer, inte minst bygg- och transportsektorerna. I ett scenario målas den södra delen av landet ut med energisnål kunskapsindustri, medan den energiintensiva industrin, som utnyttjar

\footnotetext{
${ }^{59} \mathrm{http}: / /$ www.tekes.fi/sv/community/Nyheter/478/Nyhet/1334?name=GIGA+starkte+och+internationalise rade+Finlands+datakommunikationsbransch

${ }^{60} \mathrm{http}: / /$ www.statsradet.fi/toiminta/tulevaisuusselonteko/sv.jsp
} 
naturresurser effektivt, finns utanför det s.k. Trängselfinland. Allt detta ställer stora krav på informationstekniken.

Det bör också uppmärksammas att Finland är ordförandeland för Nordiska ministerrådet år 2011 och till huvudtema för ordförandeskapet har valt hantering av klimatförändringarna på alla nivåer. Ett mål är att de nordiska länderna ska få en ännu synligare roll som en stark och enad klimatpåverkare. På området utbildning och forskning betonas att man ska dra nytta av elektroniska verktyg och virtuell mobilitet. I fokus för programmet finns ambitionen om ett starkare informationssamhälle med eScience, elektroniska tjänster och forskningsinfrastrukturer. Det förutsätter bl.a. användning av IKT på ett effektivt sätt.

Tekes innovationsstrategi ${ }^{61}$ och målsättningar handlar till stor del om betydelsen av hållbar tillväxt och vägar för att nå dit. Riktlinjer och åtgärder handlar delvis om kompetens för att åstadkomma innovationer liksom digitaliseringen som förnyare av service och produktion. Det förutsätter användning av IKT på olika sätt.

Självklart anser bedömare i Finland att utnyttjandet av IKT är av vikt i utvecklingen på det näringspolitiska området. Som ett komplement till Tekes övriga program finns en ny stimulansordning med tydligt sikte på grön tillväxt och som lanseras i full skala under hösten 2011. Det nya programmet ska identifiera potentiella tillväxtområden för affärsverksamhet och bl.a. medverka till energi- och materialeffektivitet i både produktion och tjänstesektorn. Programmet riktar sig till i första hand näringslivet inte minst stora företag. Samarbete med ministerierna förutsätts. Första fasen innehåller information, prognosverktyg $\mathrm{mm}$ och tar sikte på företagens intresse att agera för grön tillväxt. IT- och IKT-lösningar har här sin givna roll. Andra fasen innehåller konkreta utvecklingsprojekt.

I Finland är tjänsternas andel av såväl sysselsättningen som BNP över 70 \%. Landet är i mångt och mycket ett tjänstesamhälle och välfärden är beroende av tjänsternas produktivitet. Enligt Arbets- och näringsministeriet har tjänsteinnovationer ${ }^{62}$ stor betydelse för det finska näringslivet och samhällsutvecklingen. Nya affärsmodeller, kontaktytor mot kund och tjänster utvecklas fortlöpande, och inom logistiktjänsterna har genom utnyttjande av IKT uppstått en ny typ tjänsteutbud. Det är rimligt att tro att en del av detta kommer att medföra en minskad miljöbelastning.

Ett aktuellt exempel på en politisk bedömning har samband med Nokias omstrukturering våren 2011. Nokias lösningar medför visserligen avsevärda följder för forsknings- och produktutvecklingsverksamheten inom ICT-branschen i Finland. Men genom ett snabbt och effektivt agerande kan dock detta hot vändas till en möjlighet, enligt näringsministern och arbetsministern. ${ }^{63}$

\footnotetext{
${ }^{61} \mathrm{http}: / /$ www.tekes.fi/sv/community/Strategi/395/Strategi/1492

${ }^{62} \mathrm{http}: / /$ www.tem.fi/?l=sv\&s=2726

${ }^{63} \mathrm{http}: / /$ www.tem.fi/?89510_m=102663\&l=sv\&s=2468
} 


\subsection{IT har en plats i finsk utbildning, delvis med grön inriktning}

I Finland har under åren 2008-2010 funnits ett särskilt projekt för Informations- och kommunikationsteknologi i skolornas dagliga arbete. En bakgrund är vikten av att även under kommande år stödja samhällsomvandlingen med hjälp av bl.a. IKT. Projektet är gemensamt för Kommunikationsministeriet, Undervisningsministeriet, Utbildningsstyrelsen och näringslivet. En central fråga har varit lärarnas färdighet att utnyttja webbtjänster avsedda för undervisningsbruk, en annan fråga gällde den teknik och de telekommunikationsförbindelser som finns till lärarnas och elevernas förfogande. Förslag från projektgruppen har gällt kommunikation, teknisk utrustning, pedagogiska modeller, läromedel, utveckling av skolans praxis och partnerskap mellan skolor och företag.

Bl.a. nämnda projekt har lett fram till att Finland har tagit fram en nationell plan för användning av informations- och kommunikationsteknik i undervisningen ${ }^{64}$, som börjar användas under våren 2011. I planen behandlas olika strategiska målsättningar och åtgärder, som rör bl.a. nationella mål, kunnande som eleverna behöver i framtiden, pedagogiska modeller och metoder, e-läromedel och applikationer för lärande, skolornas infrastruktur och stödtjänster, lärarnas roller och utbildning, skolans verksamhetskultur och ledarskap samt samarbete med företag och nätverkande. I dokumentet nämns också att principen om hållbar utveckling bör beaktas, alltså grön IT.

En viktig bakgrund till den nya planen är dagens situation, som innebär att det fortfarande råder mycket stora skillnader mellan olika finska skolor när det gäller användningen av informations- och kommunikationsteknik i undervisningen. I en del skolor är datorer och nätverksanslutningar en normal del av skolans vardag, andra skolor är bara i startgroparna. Mängden och standarden på utrustningen är också mycket olika i olika skolor. På vissa håll har eleverna vid behov tillgång till en personlig dator, medan andra skolor har en dator per över fyrtio elever. Största delen av alla läromedel är fortfarande tryckta text- och arbetsböcker eller fotokopior.

Av viss betydelse för hållbarhet och informationsteknik är att Finland är medlem i ENSI65, FN:s nätverk för utbildning för uthållig utveckling i utbildningssektorn. Arbetet inom ramen för detta nätverk har bl.a. bidragit till olika projekt för framsteg rörande uthållig utveckling inom landets utbildning. Mellan mötena har lärare och andra berörda arbetat med hjälp av elektronisk kommunikation och olika mjukvaruapplikationer.

64 http://www.oph.fi/meddelanden/2011/011

65 http://www.ensi.org/Members/Member_countries/Finland/ 
Ett exempel på ett lärosäte som utbildar i Grön IT är Åbo Akademi som tar fasta på begreppet Cloud computing66, vilket baserar sig på användning av programvara över Internet. Undervisning och utveckling sker inom ramen för projektet Cloud Software Program, där man söker efter effektivare lösningar för såväl hård- som mjukvara.

Ett annat lärosäte med betydande fokus på grön utveckling är Aaltouniversitetet ${ }^{67}$ nära Helsingfors. Cleantech, energi och miljö är väsentliga inslag i verksamheten. Campus ska genomsyras av hållbarhet. I undervisning och forskning finns flera inslag av Grön Tillväxt. Det finns tvärgående program och projekt mellan universitetets tre grenar: Handelshögskolan, Konstindustriella högskolan samt Högskolorna för teknik. I utbildningen betonas bl.a. ansvarsfull affärsverksamhet, samhällsplanering och informationsteknik (IT).

$66 \mathrm{http}: / /$ web.abo.fi/meddelanden/forskning/2010_09_cloud.sht

$67 \mathrm{http} / / /$ www.aalto.fi/sv/ 



\section{Island}

\subsection{Aktörer och inriktning}

Island är ansett vad gäller kunskap inom IKT och har blivit rankad tämligen högt upp på listor över utvecklandet av IKT, t.ex. World Economic Forum ${ }^{68}$ Och i The Global Information Technology Report 2010-2011, där Island kom på en 16:e plats (av 138 länder). ${ }^{69}$ År 2008 fanns det 433 stycken IT-företag med drygt 6100 anställda. ${ }^{70}$ Islands IKT-kunskap har byggts upp huvudsakligen genom branscherna som rör livsmedelshantering med utrustning med hög grad av automation, fiskeribranschen som blivit alltmer datoriserad och även banksektorn med transferreringar och kommunikation etc. Samtidigt rankas landet lägre än övriga Norden i aspekter som rör e-governement och e-participation: rankad som nummer 22 år 2010 i FN:s E-government development index och även lågt i FNs E-participation Index. ${ }^{71}$

$93 \%$ av hushållen på Island har dator och $87 \%$ uppger att de har Internetaccess. ${ }^{72} 68 \%$ av invånarna uppger att de fătt information av offentliga myndigheter via internet. ${ }^{73}$ Antalet med Intenetaccess och tillgängligheten för IT-buren information är med andra ord hög.

IT-frågor hanteras av Inrikesministeriet i Island. ${ }^{74}$ Det har funnits statlig styrning och koordinering av IT och utvecklingen mot informationssamhälle sedan mitten av 1990-talet. År 1996 publicerade regeringskansliet det första offentliga dokumentet rörande informationssamhället. Både den offentliga och privata sektorn är viktiga aktörer i ITsamhället. Vid mitten av 1990-talet publicerade även departementet för utbildning, forskning och vetenskap ett av sina första policydokument rörande informationssamhället och en avdelning för utveckling av IT skapades inom departementet 1999/2000.

Flera politiska dokument har lagts fram som berör strategier och visioner för Islands utveckling vad gäller IT och IKT, bl.a. Iceland, the enation. Den är inriktad på tjänster, effektivitet och framtida framsteg.

\footnotetext{
68 https://members.weforum.org/pdf/Global_Competitiveness_Reports/Reports/GITR_2004_2005/ Networked_Readiness_Index_Rankings.pdf

69 The Global Information Technology Report 2010-2011, 2011, World Economic Forum.

70 http://www.statice.is

${ }^{71}$ E-Government Survey 2010, United Nations, som mäter tillhandahållandet av offentliga tjänster till medborgare och företag, tjänster inom områden som hälsa, arbetsliv och utbildning. E-participation index, 2010, United Nations. E-participation brukar definieras som "ICT-supported participation in processes involved in government and governance".

72 http://www.statice.is

$73 \mathrm{http}: / /$ www.statice.is

${ }^{74}$ http://www.pfs.is/default.aspx?cat_id=101
} 
Bl.a. talas om att samla olika tjänster på en hemsida, vilket idag är gjort (www.island.is) och där finns bl.a. alla offentliga tjänster samlade. ${ }^{75}$ Andra strategier och styrdokument kan nämnas är the Telecom Policy, Utbildningsministeriets plan för elektroniska journaler och hälso-nät, Utbildningsdepartementets strategi om IT i utbildning, kultur och vetenskap, Den nationella policyn för gratis och open-source software, Regeringens upphandlingspolicy $\mathrm{m} \mathrm{fl}$.

Island har många gånger lyfts fram som en optimal placering när det gäller datacenter, med geotermisk värme kombinerat med kallt havsvatten för en helt koldioxidneutral miljöpåverkan. Dessutom kan landet med sitt geografiska läge fungera som en hub mellan Europa och USA. Att skapa datacenter har fătt en rush efter den ekonomiska krisen i Island. Valutan har devalverats, det finns god IT-erfarenhet och kunskap samt tillgång på grön el och effektiva nät. ${ }^{76}$

Det isländska datacentret Thor har nyligen etablerats efter en uppbyggnadsfas på 18 månader. Den första stora utländska kunden är norska Opera som väljer att köra all trafik för Opera Mini-användare i Europa, Afrika och Asien via Island. Datacentret Thor ansluter till Europa via undervattenskablarna Farice (till Storbritannien) och Danice (till Danmark), driftade av det isländska telekomföretaget E-Farice. ${ }^{77}$

En annan fråga som är aktuell när det gäller IT/IKT på Island är frågan om cloud computing där exempelvis företaget Greenqloud nyligen har etablerats. Affärsidén är helt enkelt att hyra utrymme i datacenter i Island för att sedan hyra ut till kunder över hela världen som har ambitionen att hantera sitt ekologiska fotavtryck och vill använda förenyelsebar energi som ju Islands drivs av. ${ }^{78}$

\subsection{Några viktiga områden för Island inom IKT}

I sin strategi, Iceland 2020, tar Island fasta på att trots god access till Internet, hög användningen härav, god teknisk infrastruktur och goda IT-kunskaper, är inte utbudet av IT-baserade tjänster så högt. De digitala offentliga tjänsterna önskar Island ska öka och som mål har man därför bl.a. satt följande: år 2020 ska Island vara bland topp 10-länderna på FN:s E-government development index och E-participation Index. År 2020 ska hög-teknologisk industri svara för $10 \%$ av BNP och $15 \%$ av exportvärdet.79

\footnotetext{
75 Iceland, the e-nation - Icelandic Government Policy on the Information Society 2008-2012.

$76 \mathrm{http} / /$ gigaom.com/cleantech/greenqloud-icelands-clean-power-cloud-computing-co/

7720 miljoner användare flyttar till Island, 2010-11-01, TechWorld.

$78 \mathrm{http} / /$ gigaom.com/cleantech/greenqloud-icelands-clean-power-cloud-computing-co/

79 Iceland 2020 - governmental policy statement for the economy and community, 2011, Islands regering

Knowledge, sustainability, welfare, 2011, Islands regering.
} 
Island menar också att de idag befintliga goda kommunikationerna måste vidmakthållas då risken finns att konkurrenskraften minskar om utvecklingen av fiberoptik avstannar.

Island har geotermisk produktion av energi samtidigt som de har en del energiintensiv industri, t.ex. tillverkning av aluminium. Grunderna för den energiintensiva industrin anses behöva stärkas och fokus måste läggas på nya industrier som exempelvis solceller, datalagring, grödor odlade i geotermiskt uppvärmda växthus etc, en utveckling som stärks av IKT-användning. 80

I den investeringsplan som finansdepartementet har ansvar för, betonas områden som transport och energi, kommunikation och dataöverföring - områden där IKT har en stor betydelse. ${ }^{81}$ I IT-policyn talas även om behovet att arbeta för mer outsourcing och informationsteknologi inom den privata sektorn för att öka konkurrenskraften hos isländska företag. ${ }^{82}$

\subsection{Infrastrukturen för IKT är på plats i isländsk utbildning}

Liksom i andra länder ses teknikutvecklingen som en av de största drivkrafterna för förändring och utformare av framtidens samhälle. Med en geografi och befolkningsbild som Island har ses IT/IKT och distansutbildning etc. som en möjlighet att motverka avfolkning på landsbygden. 83

Det pågår en del forskning om IT i utbildning etc. vid Reykjaviks universitet. Det har förekommit satsningar och projekt för att öka användningen av IT I skolorna, t.ex. LearnICT som vänder sig till lärare och elever. 84

Användningen av IKT i skolor stöds av lokala myndigheter genom investeringar i resurser och utbildning. Forskning indikerar dock att undervisningspraxis och det (traditionella) sätt skolor är organiserade i klassrum och schema motverkar användningen av IKT och digitala läromedel, även om det finns goda exempel där individuella lärare har lyckats väl. ${ }^{85}$

OECD lyfter i en granskning fram att det isländska utbildningssystemet fungerar väl - vilket kan både vara en främjare och ett hinder för nya metoder som digitalt lärande. Systematisk utvärdering och feedback

\footnotetext{
802020 - Moving Iceland Forward initiative, 2010, Styrgruppen för 2020 - Moving Iceland Forward initiative.

81 Iceland 2020 - governmental policy statement for the economy and community, 2011, Islands regering.

82 Iceland, the e-nation - Icelandic Government Policy on the Information Society 2008-2012.

83 Framtidens utbildning i Norden - konkurrens och samverkan i en globaliserad värld , 2009, Nordiska ministerrådet.

84 "Please don't talk while I am interrupting!" Voices heard in the construction of the information and technology curriculum in Iceland, 2004, M. Allyson Macdonald and Thorsteinn Hjartarson, Iceland University of Education

${ }^{85}$ www.oecd.org/dataoecd/10/7/41848715.pdf
} 
tycks enligt OECD saknas, vilket gör att satsningar riskerar att inte vara fullt genomtänkta. ${ }^{86}$

Studier har visat att skolorna ofta är väl utrustade när det gäller datorer och support. Vidareutbildning för lärare anses också god. Däremot tycks inte IT användas i så hög utsträckning i undervisningen och även här visar studier att skolledare ser detta i högre grad prioriterat än vad lärarna själva gör. Datorkunskap och informationsstudier står på schemat i de flesta skolor, men tycks läras ut separat, d v s ingen integrering av IT i övriga ämnen. ${ }^{87}$ Även OECD pekar på att intresset för att använda IT i utbildningen är lågt på Island, men påpekar att elever använder IT i hög utsträckning utanför skolan.

${ }^{86}$ OECD study on learning resources as systemic innovation, Country case study report on Iceland, 2008.

87 "Please don't talk while I am interrupting!" Voices heard in the construction of the information and technology curriculum in Iceland, 2004, M. Allyson Macdonald and Thorsteinn Hjartarson, Iceland University of Education. 


\section{Norge}

\subsection{Aktörer och inriktning}

Norges rankas på 6:e plats i världen i "digital economy ranking"88 och som nummer nio i The Global Information Technology Report 2010$2011^{89}$ IKT-branschen är i sig själv en av de största i Norge och mer än en tredjedel av alla jobb är högteknologiska. ${ }^{90}$ Intervjupersoner pekar på att oljebranschen har drivit den teknologiska utvecklingen med ITlösningar.

Övergripande ansvar för Norges IT-politik är Fornyings-, administrasjons- og kirkedepartementet (FAD). ${ }^{91}$ Satsningen eNorge 2009 kom till för att stödja den norska regeringens IKT-politik för fortsatt tillväxt och värdeskapande samt omställningen av offentlig sektor. Regeringen pekade på goda forskningsmiljöer, hög digital kompetens bland befolkningen, hög nivå av IT-investeringar och en väl utbyggd ITinfrastruktur. Det önskades ett resultat sett ur ekonomiskt perspektiv, men även åtgärder som hade bäring på mer kvalitativa perspektiv som sociala, kulturella och demokratiska resultat. ${ }^{92}$

År 2008 skapades Direktoratet for forvaltning og IKT (Difi), vars uppgifter är att utveckla och förnya offentlig sektor, stärka samordningen och erbjuda gemsamma lösningar. ${ }^{93}$ Här finns flera utpekade arbetsområden som har positiv påverkan på miljö och uthållighet, men det är inte syften som explicit står i fokus för verksamheten eller så som den beskrivs.

Enova är en aktör helt inriktad på att bistå i övergången till en mer miljövänlig energianvändning och är involverad i främjandet av nya elteknologier, smart grids etc. ${ }^{94}$ Innovasjon Norge arbetar också med att stödja och främja IKT som en del i grön tillväxt, t.ex. genom användandet av IKT inom byggsektorn och hälsorelaterad IKT. ${ }^{95}$ Forskningsrådet stödjer IKT-forskning inom exempelvis energieffektiva byggnader och el-fordon. ${ }^{96}$

En fråga norsk IKT-politik inriktar sig på är som nämnts ovan, värdeskapandet knutet till användningen av offentliga data. Det kan finnas en stor marknadspotential i att offentliga data bättre kan nyttjas och ges

\footnotetext{
88 Digital economy rankings 2010. Beyond e-readiness, Economist Intelligence Unit.

89 The Global Information Technology Report 2010-2011, 2011, World Economic Forum.

90 The 2007 e-readiness rankings - Raising the bar, 2007, Economist Intelligence Unit.

${ }^{91} \mathrm{http} / / /$ www.regjeringen.no/nb/dep/fad/tema/ikt-politikk/ikt-politikken.html?id=630885

${ }^{92}$ eNorge 2009 - det digitale spranget, 2005, Moderniseringsdepartementet (numera Fornyings-, admin-

istrasjons- og kirkedepartementet).

93 www.difi.no

94 http://www.enova.no

95 http://www.innovasjonnorge.no/Energi-og-miljo/

96 http://www.forskningsradet.no
} 
större tillgänglighet, genom att öka värdeskapande och innovation i näringslivet, genom produktion av nya eller förbättrade varor eller tjänster. Från politiskt håll pekas också på att mer effektiv produktion och användning av data internt i den offentliga sektorn även kan ge bättre resursanvändning i densamma samt i interaktionen mellan offentlig och privat sektor. Dessutom stärks demokratin med mer tillgängliga data. ${ }^{97}$

\subsection{Några viktiga områden för Norge inom IKT}

De prioriterade insatsområdena i Norges nationella IT-arbete uppges vara: 98

- Säkra ett informationssamhälle för alla, bl.a. genom utbyggnad av bredband, öka kunskapen om IT bland invånare etc.

- Bidra till innovation och värdeskapande i näringslivet genom att underlätta för utveckling och tjänster baserade på digitalt innehåll, tillgängliggöra offentliga data och främja smarta klimatvänliga IKTlösningar

- Stimulera tillväxt och utveckling i IKT-näringen, bl.a. genom att skapa goda ramar för elektronisk handel, tjänsteutveckling och innovation

- Goda offentliga självbetjäningslösningar och effektiv förvaltning, bl.a. genom att samordna offentliga IKT-projekt, utveckla förvaltningsstandards för gemensam offentlig upphandling, elektronisk ID etc.

Fornnyingsministern betonade i ett tal på IT-tinget 2010 att uthållig utveckling är en av de mest betydelsefulla aspekterna av IT-politiken och att detta kommer att bli än viktigare framöver. Omställningen till att bli ett samhälle med smart förvaltning kräver en massiv IKT-insats, menade ministern. Det handlar om sådana saker som energistyrda byggplatser, smarta elnät, intelligenta transport- och logistiksystem och nya elektroniska tjänster. Samtidigt pekades på behovet om att göra den egna IKT-användningen mindre energikrävande, göra statens datacenter grönare, ställa krav vid upphandling och underlätta för grön IKT som tillväxtbransch. ${ }^{99}$

Smarta el-nät är en viktig fråga i Norge. Bl.a. har The Norwegian Smartgrid Centre skapats av en rad aktörer inom akademi och näringsliv med anledning av denna fråga. 100 "Kompetensen börjar byggas upp", som en intervjuperson uttryckte det.

\footnotetext{
97 Markedspotensial ved økt tilgjengeliggjøring av offentlig data, Rapport nr. 2011-01, Oslo Economics.

98 http://www.regjeringen.no/nb/dep/fad/tema/ikt-politikk/ikt-politikken.html?id=630885

${ }_{99}$ http://www.regjeringen.no/nb/dep/fad/aktuelt/taler_og_artikler/minister/taler-og-artikler-avfornyings--og-kirke/2010/betydningen-av-ikt-for-norge.html?id=615661

100 http://www.forskningsparken.no/HCoE-NO/Nyheter/NCE-Halden-med-pa-a-stifte-The-NorwegianSmartgrid-Centre/
} 
Inom fem år ska alla norska hem ha tvåvägskommunikation knutet till elmätning vilket torde ge sysselsättning till norska IKT-branschen.

IKT-branschen har gått samman i en gemensam sammanslutning och driver sedan 2007 projekt för bättre klimat, Grønn IT. De arbetar bl.a. för att IT ska användas på bästa sätt för att minska de totala klimatdrivande utsläppen i andra sektorer. t.ex. digitalisering av kommunikation med medborgarna, geografiska informationssystem (GIS) som kan simulera och synliggöra potentiella miljöproblem, smartare logistik- och transportlösningar, smartare elnät och lösningar för smart energistyrning $\mathrm{i}$ byggbranschen. ${ }^{101}$

Användningen av IKT har bidragit till bättre hälsa och miljö, både genom att minska energiförbrukningen och på annat sätt. Några exempel på utvecklingen i samhället: ${ }^{102}$

- Oslos nya T-bana använder nästan hälften så mycket energi än de som användes på 1960-70-talet. Detta åstadkoms mestadels genom elektroniskt styrd tillbakamatning av el till nätet vid inbromsning

- Dagens höghastighetståg, TGV, använder vid samma hastighet ca en tredjedel så mycket energi som första generationens TGV från tidigt 1980-tal. Detta åstadkoms i stor utsträckning genom mindre luftmotstånd som möjliggjorts i vindtunnelförsök och simulering $\mathrm{i}$ kraftfulla datorer

- Datorer har möjliggjort bättre väder- och klimatprognoser

- Videokonferenser kan ofta ersätta tjänsteresor

- S k Telependling kan ersätta fysisk transport

Rapporter och studier visar på IKT som lösningen för att hantera klimatutsläppen. Här pekas också på den offentliga sektorns betydelse för att främja IKT-användningen genom att skifta fokus från produkter till tjänster, att beakta mer miljövänlig teknik, grön upphandling, synliggöra effekter etc. ${ }^{103}$ Kunskap, insikt och teknologi finns i viss utsträckning. Intervjupersoner pekar ändå på att IKT idag inte är en del av norsk klimatpolitik och att det finns en fara i att styrmedel kan motverka varandra.

\subsection{Sporadisk användning av IKT i utbildning}

Undersökningar visar att $17 \%$ av grundskolorna och $96 \%$ av vidareutbildningen har skaffat en digital lärplattform (kan ibland också benämnas LMS, Learning Management Systems). Den utvecklingen tog fart

\footnotetext{
101 http://www.gronnit.no/cosmos2/show.do?id=1422

${ }^{102} \mathrm{http}: / /$ www.skolenettet.no/moduler/templates/Module_Dictionary_Word.aspx?id=50009\&epslanguage=NO

${ }^{103}$ IKT og klimagassutslipp, 2009, Pöyry Group.
} 
under 2000-talet. 104 Studier på området visar att digitala lärplattformar är en viktig katalysator för skolors IKT-satsning och utvecklingen av digital kompetens. Bättre pedagogiskt nyttjande av LMS kräver dock bättre möjligheter för delning av digitalt innehåll. Det finns en plattform för skolor att ta del av digitala läromedel. Den innehållsportalen ska förenkla tillgången till digitala läromedel för grundskola och högre utbildning. ${ }^{105}$

Det finns även initiativ för att öka användningen av IKT i skolan, t.ex. Skolenettet som är en del av Utdanningsdirektoratet. Där finns teknik och pedagogik med guidning, vägledning och speciella sidor för IKTansvariga. Exempel på insatser är projektet "LærerIKT" för att främja användningen av IKT som verktyg i skolan. 106

Studier visar på allmänt god IT-kunskap i skolan, både bland elever och lärare: $95 \%$ av eleverna i grundskolan och $92 \%$ i vidareutbildningen har tillgång till dator hemma och $80 \%$ har tillgång till Internet hemma. Motsvarande $90 \%$ av lärarna har tillgång till dator hemma och 80 \% har tillgång till dator hemma. 95 \% av lärarna använder också dator till skolrelaterat arbete. Var tredje använder datorn mer specifikt till förberedelse, genomförande av undervisningen och efterarbete. 107

Dock har studier även i Norge visat på sporadisk användning av IKT i undervisningen, trots stora satsningar. Oftast används internet endast för att söka information. Strukturella hinder som lärarnas tid, organisering i klassrum och lärarnas professionella vidareutbildning nämns. ${ }^{108}$ Lärarutbildningen strävar dock efter att ta fasta på att föra in IKT, även om arbetet inte tycks framskrida så fort. 109

Främjandet av IKT-användningen i utbildningen fortsätter. År 2010 skapades ett nationellt center, Senter for IKT i utdanningen, utifrån övertygelsen att IKT bidrar till högre kvalitet i inlärningen, stärkt lärande och bättre lärandestrategier för barn, elever och studenter. Centret ska arbeta för att utbildningssektorn bättre ska nyttja potentialen som ligger i IKT för utbildning, lärande och innovation genom en mer holistisk syn på IKT i skolan.110

Bilden över fördelningen av elever som studerar olika ämnen är gemensam med många andra länder. Även Norges regering önskar fler studenter till naturvetenskapliga och framförallt tekniska ämnen. Det finns en klar övervikt på elever som söker sig till samhällsvetenskapliga ämnen. ${ }^{111}$ Intervjupersoner pekar på behovet att folk kan jobba med

\footnotetext{
104 Digitale læringsplattformer - en mulig katalysator for digital kompetanse i grunnopplæringen, 2006, Utdannigsdirektoratet.

105 http://www.diglib.no/

$106 \mathrm{http}: / /$ www.skolenettet.no/moduler/templates/Module_Article.aspx?id=20870\&epslanguage=NO

107 Elevers och læreres IKT-kompetanse, 2002, Kunnskapsdepartementet.

108 www.oecd.org/dataoecd/31/45/2732632.pdf

109 ICT in Initial Teacher Training, 2009, OECD.

110 http://www.iktsenteret.no/et-samarbeid-om-ikt-i-og-utdanning

111 http://www.udir.no/Artikler/_Statistikk/Elevers-fagvalg-i-videregaende-opplaring-skolearet-20102011/
} 
utveckling och forskning inom naturvetenskapliga och tekniska ämnen för att kunna hantera morgondagen klimat- och miljöproblem. 



\section{Sverige}

\subsection{Aktörer och inriktning}

Sverige placerar sig 2010, liksom föregående år, i topp jämte Danmark i rankingen av "influence of ICT in economic (and social) progress" ( $\mathrm{t}$ o m år 2009 mättes snarare "e-readiness"). ${ }^{112}$ Även enligt World Economic Forums lista hamnar Sverige i topp, här på en första plats. ${ }^{113}$ Det innebär ett gynnsamt klimat för e-business och allmänt goda Internetbaserade möjligheter samt en hög grad av individers och näringslivs användning av digitala varor och tjänster. Samtidigt fanns under den senaste finanskrisen tecken på en minskande vilja att investera i grön IT114, detta enligt Almega som regelbundet tar fram ett Grön IT-index.115 Fokus ligger i hög grad på att börja realisera de potentialer och möjligheter som finns. Vidare finns röster som påpekar att svenska företag inte på allvar har kommit igång med att göra affärer av IT och miljöfrågan, även om detta är på väg att vända. Bl.a. har vissa regler ansetts bromsa utvecklingen av miljö-IT. Som en bedömare har påpekat: "Skatteavdrag ges för att ta bilen till jobbet, men inte för att installera ett videokonferenssystem så att man lättare kan arbeta hemifrån."

När det gäller "Grön IT" konstateras i olika sammanhang att den svenska IT-sektorn, med de tjänster och tekniklösningar som erbjuds, är ett område som både anses vara klimatsmart i sig (med rätta anpassningar) och som kan utveckla andra sektorer, bl.a. kan när det gäller smarta IT-transportsystem, som begränsar utsläpp av koldioxid. Vissa bedömare anser dock att en given fråga på skolans område är synen på digital kompetens - och att Sverige inte alls har kommit så långt som många andra EU-länder när det gäller arbetet med att integrera digital kompetens i skola, vuxenutbildning och i lärarutbildning. ${ }^{116}$

Sveriges regering och myndigheter har tagit en rad initiativ på området Grön IT. På en särskild sida på Internet ${ }^{117}$ har information samlats, såsom policydokument ( $\mathrm{t}$ ex Digital Agenda), faktarapporter i ämnet, hänvisningar till nationellt och internationellt arbete etc. Sverige har också en särskild minister inom Näringsdepartementet med utpekat

\footnotetext{
112 The 2007 e-readiness rankings - Raising the bar, 2007, Economist Intelligence Unit. 113 The Global Information Technology Report 2010-2011, 2011, World Economic Forum.

114 http://www.almega.se/web/Gron_IT_nr_3.aspx

115 Grön IT-indexet har baserats på en undersökning där ca 1000 IT-ansvariga i både privat och offentlig sektor runtom i Sverige har svarat på frågor om hur de ser på IT:s miljö effekter och hur de arbetar för att dra nytta av IT på bästa möjliga sätt för miljön.

$116 \mathrm{http}: / /$ computersweden.idg.se/2.2683/1.333556/sverige-behover-hallbar-it-politik

117 www.regeringen.se/gronit
} 
ansvar för IT-frågor. Bland många andra frågor handlar arbetet med den digitala agendan bl.a. om att fler ska kunna bli mer delaktiga i det digitala samhället, hur vi ännu bättre kan använda IT för att nå största möjliga miljövinster, och hur svenska företag samtidigt kan skapa nya exportframgångar samt hur svenska skolor - liksom även vården och omsorgen - ska kunna utnyttja IT-hjälpmedel i större utsträckning. Vidare har det statligt tillsatta Globaliseringsrådet i rapporten "Bortom krisen" pekat på att den digitala infrastrukturen är en avgörande förutsättning för tillväxt och utveckling.

År 2008 lät Näringsdepartementet ta fram en nationell förstudie om IT för miljön, kallad Från vision till verklighet. ${ }^{118}$ Där ges en översikt över insatser på området IT och miljö samt vissa förslag till åtgärder. Bland förslagen märktes en pådrivande samordningsfunktion inom regeringskansliet, tydliga och uppföljningsbara mål, fokus på vissa områden där belastningen i samhället är som störst samtidigt som det finns stor potential att göra nytta. Den nämnda sajten Grön IT är delvis ett resultat av denna förstudie.

Det finns en särskild förordning om miljöledning i statliga myndigheter. Där anges att myndigheterna så långt det är möjligt ska använda energieffektiv informationsteknik (IT) som verktyg för att miljöanpassa sin verksamhet. Naturvårdsverket konstaterar i sin rapport i april 2011 Miljöledning i staten ${ }^{119}$ att $88 \%$ av myndigheterna anger att de använt IT för att minska sin energiförbrukning och $91 \%$ att de använt IT för att minska antalet tjänsteresor.

Två statliga dokument under 2009 resp. 2010 - dels Agenda för IT för miljön 2010-2015, dels IT för en grönare förvaltning120 - slår fast mål och handlingslinjer, så att miljöanpassad IT används för att minska statlig miljöbelastning, och detta ska gälla inom hela den statliga myndighetssektorn. Naturvårdsverket hade gjort ett kartläggningsarbete och tagit fram indikatorer, vilka också framgår av den nämnda rapporten Miljöledning i staten. Viktiga områden som tas upp gäller bl.a.:

- Anskaffning (upphandling) av varor och tjänster, med mål om miljökrav på IT-området

- Drift och användning, bl.a. mål för minskad energianvändning i ITverksamheten

- Resor och möten, med mål om fler resfria möten

En rekommendation till myndigheterna är att utarbeta en tydlig policy för IT, att utbilda personal i miljöanpassad upphandling av IT samt att följa upp anskaffningen av IT ur ett miljöperspektiv.

\footnotetext{
118 http://www.regeringen.se/content/1/c6/09/83/97/80e1d358.pdf

${ }^{119} \mathrm{http}: / /$ www.naturvard sverket.se/Documents/publikationer6400/978-91-620-6422-8.pdf

120 http://www.sweden.gov.se/content/1/c6/14/95/86/71a29882.pdf
} 
Sverige har spelat en betydande roll i det Europeiska arbetet med The digital Agenda. På basis av EU:s strategi arbetar regeringen i skrivande stund fram en digital agenda för Sverige för att "... samordna åtgärder på IT-området inom till exempel säkerhet, infrastruktur, kompetensförsörjning, tillit, tillgänglighet, användbarhet, standarder, entreprenörskap och innovation." 121 Den svenska regeringen betonar vikten av att bidra till ett grönare samhälle. Den nya digitala agendan utformas i dialog med såväl myndigheter, företag som civilsamhälle. Det finns också ett forum för digital agenda där vem som helst kan göra inlägg, debattera eller lyfta frågor. ${ }^{122}$ Det finns även ett digitaliseringsråd inrättat av regeringen, vars funktion både ska vara rådgivande och utgöra forum för strategisk diskussion ${ }^{123}$ samt en $e$-delegation med fokus på eförvaltning i den offentliga sektorn. ${ }^{124}$

En rapport om IT och energieffektivisering från Regeringskansliet och IT- och Telekomföretagen inom Almega ger en övergripande bild av utvecklingen i Sverige för att svara upp mot EU-kommissionens meddelanden och rekommendationer på området IT och energieffektivisering. Den visar bl.a. ett antal utmaningar, men också goda exempel, på delområdena IT/Telekom, Byggnader/Fastigheter, Energi och Transport/Logistik.

Det kan nämnas att staten och myndigheterna i viss mening vill agera som en föregångare. Regeringskansliet våren 2009 tog initiativ till en benchmarking: Sammanfattning av Grön IT-Scorecard, Gartner, maj, 2009125 där det konstaterades att Regeringskansliet hade en utvecklad policy för hållbar utveckling liksom handlingsplaner på området, men att miljöpolicyn för IT var outvecklad, även om teknikoptimeringen i sig hade kommit långt.

Det kan också nämnas att en konferens om IT för ett grönare samhälle anordnades i Regeringskansliets lokaler Rosenbad i november 2010 under IT- och regionminister Anna-Karin Hatt. En särskild poäng gjordes av att flera deltagare kunde följa seminariet via webben. Som ministern påpekade handlade ju seminariet i grund och botten om just detta - om hur vi kan använda IT för att skapa ett smartare, effektivare samhälle, bland annat genom mindre resande. Det angavs att detta krävdes inte minst därför att Sverige under de närmaste åren ska minska sina utsläpp av växthusgaser med $40 \%$, d.v.s. klart mer än EU i övrigt. IT sades vara en del av problemet, men samtidigt en viktig del av lösningen. Enligt EU-kommissionen står produktionen och användningen av IT för $2 \%$ av de globala koldioxidutsläppen. Men samtidigt bedömer man att det finns en väldig outnyttjad potential, och att vi, om vi använde IT på

\footnotetext{
121 http://www.sweden.gov.se/sb/d/14375

$122 \mathrm{http}: / /$ digitalagenda.ning.com/

${ }^{123}$ http://www.sweden.gov.se/sb/d/14479/a/162816

124 Delegation för e-förvaltning, Dir. 2009:19

${ }^{125} \mathrm{http}: / /$ www.sweden.gov.se/content/1/c6/14/52/70/1d25e4fe.pdf
} 
rätt sätt, skulle kunna minska våra koldioxidutsläpp med $15 \%$. Den politiska ambitionen är till fullo utnyttja IT:s potential för ett grönare samhälle, så att vi kan kombinera att leva ett gott liv med att ta ansvar för våra gemensamma, ändliga naturresurser.

Bland övriga statliga organisationer som särskilt har uppmärksammat området hållbar IT finns bl.a. Energimyndigheten, som i ett antal program berör möjligheter till energibesparing och därmed även IT och miljöfrågor. För att stärka Näringsdepartementets möjligheter att utveckla svensk IT-politik har myndigheten Tillväxtanalys kartlagt indikatorer som ett Underlag för IT-politiska insatser. ${ }^{126}$ Bl.a. refereras regeringens initiativ under konferenser $\mathrm{mm}$ i samband med det svenska ordförandeskapet i EU.

\subsection{Några viktiga områden för Sverige inom IKT}

Sammantaget anses i Sverige - liksom i Norden i stort - att både KIBS127 och IKT är en betydelsefull sektor respektive bransch i sig, men även för utveckling av andra företag och offentliga verksamheter - inte minst för att minska miljöbelastningen.

Byggnader/Fastigheter, Energi och Transport/Logistik ses som områden med framtida utmaningar (se även avsnitt 6.1 ovan) och där det ses behov av olika insatser.

Vinnova finansierar viktiga IKT-projekt och stöder utvecklingen av digitalisering i samhället. E-förvaltning stöds genom program som Citizens' Services, år 2010-2013, som är samfinansierat med Nordforsk. Syftet är att etablera ett nordiskt-baltiskt samarbete och ett gemensamt forsknings- och innovationsprogram inom området e-förvaltning. Ehälsa är ett annat område som Vinnova arbetar med, där en utgångspunkt är IT-strategin för vård och omsorg, bl.a. genom internationellt samarbete och samordnad utveckling. vissa projekt tar sikte på att förbättra för företagen, andra på att underlätta för människor att vara delaktiga, kreativa och företagsamma, vilket leder till en hållbar utveckling av ekonomi och välfärd. 128

Organisationen IT-forum ${ }^{129}$ är en sammanslutning av bl.a. landstinget och kommunerna i Stockholms län. Uppdraget är att verka för införandet av en modern e-förvaltning - både i regionen och på ett nationellt plan. Frågorna handlar om eSamhället samt den nationella strategin för eHälsa. Man vill driva verksamhetsutveckling med stöd av IT. En av flera effekter kan bli ökad effektivitet och tillväxt med mindre miljöbelastning.

\footnotetext{
126http://www.tillvaxtanalys.se/tua/export/sv/filer/publikationer/rapporter/Rapport_2009_15.pdf

127 Knowledge Intensive Business Sector.

128 www.vinnova.se

${ }^{129} \mathrm{http} / /$ www.ksl.se/svenska/vara-uppdrag/andra-verksamheter-inom-ksl/it-forum-stockholms-lan.html
} 
I Sverige arbetar regeringen i skrivande stund fram en digital agenda för Sverige för att "... samordna åtgärder på IT-området inom till exempel säkerhet, infrastruktur, kompetensförsörjning, tillit, tillgänglighet, användbarhet, standarder, entreprenörskap och innovation".130 En framgångsrik sådan samordning kan leda till både tillväxt och en skonsammare påverkan på klimat och miljö. Med liknande syften har regeringen tidigare tagit initiativ till att stötta digitaliseringen inom flera politikområden genom en handlingsplan för elektronisk förvaltning131, en bredbandstrategi för Sverige ${ }^{132}$ och en nationell IT-strategi för vård och omsorg. ${ }^{133}$

En medveten upphandlingsverksamhet kan påverka miljön. Det finns regionala exempel på sådana effekter. När Stockholms läns landsting, SLL, under förra året gjorde en jätteupphandling av persondatorer lades stor vikt vid att datorerna skulle vara så miljövänliga som möjligt. Omkring 40000 datorer ska bytas ut och landstinget ställde krav på låg energiförbrukning, användning av returplast, att datorerna skulle vara extra tysta samt att leverantören jobbar för att fasa ut ämnen som bly och kvicksilver i datorerna.

I den svenska debatten hörs flera röster som betonar möjligheterna och vikten av att använda IKT i en grön omställning - i Norden och globalt. Den kända debattören Dennis Pamlin, som är rådgivare på Världsnaturfonden, är en av dem som påpekar att videokonferenser (sparar flygresor och därmed bränsle) och elektroniska räkningar inte bara är smidigt - det är också lösningar som kan rädda vår miljö.

\subsection{IKT används i forskning och utbildning}

Vinnova lät hösten 2008 göra en kartläggning av svensk FoU inom området IT och miljö (VR 2009:13).134 Den innebär en översyn och förståelse av forskningsverksamhet i Sverige, med fokus på teknikens indirekta och systemmässiga effekter. Bl.a. visas en stor bredd av olika tvärvetenskapliga projekt inom IT och miljö. Många FoU-projekt kopplas till energi, transport, stadsplanering, processer, tillverkningar, byggnader, resfria möten mm. Attityder och beteenden runt IT-användningen behandlades i nästan hälften av projekten. Sådana forskningsprojekt har genomförts på flera lärosäten, med viss koncentration kring storstäderna samt i Linköping och Blekinge. Ingen av de nationella s.k. bidragsorganisationerna

\footnotetext{
${ }^{130} \mathrm{http}: / /$ www.sweden.gov.se/sb/d/14375

${ }^{131}$ Handlingsplan för eFörvaltning - Nya grunder för IT-baserad verksamhetsutveckling i offentlig förvaltning, 2008, Finansdepartementet.

132 Bredbandsstrategi för Sverige, 2009, Näringsdepartementet.

${ }^{133}$ Nationell eHälsa - strategin för tillgänglig och säker information inom vård och omsorg, 2010, Socialdepartementet.

${ }^{134} \mathrm{http}$ //www.vinnova.se/upload/EPiStorePDF/vr-09-13.pdf
} 
hade någon uttalad strategi eller etablerat bidragsprogram för just tvärvetenskaplig forskning inom just IT och miljöområdet.

Naturvårdsverkets tidigare nämnda rapport om miljöledning i staten 2010 har ett avsnitt om Grön IT samt ett särskilt kapitel om universitet och högskolor. Det är sammanlagt 34 universitet och högskolor som inkluderas i förordningen om miljöledning (SFS 2009:907). I rapporten sägs bl.a. att flertalet universitet/högskolor har tagit upp forskning och utbildning som betydande miljöaspekt. Kraven uppfylls i något lägre grad än för svenska myndigheter i allmänhet, vilket i ett längre perspektiv skulle kunna få effekter för grön IT i undervisningssystemet. I rapporten återfinns bl.a. hitta en rankinglista där Göteborgs universitet ligger i topp. Dessutom synliggörs att tre lärosäten är miljöcertifierade. Det gäller Göteborgs universitet, Högskolan i Gävle samt Mälardalens högskola.

Det kan också nämnas att Göteborgs universitet har en särskild handlingsplan för miljö och hållbar utveckling, vilken anger de övergripande målen för universitetets arbete med hållbar utveckling och hur dessa skall realiseras av universitetets verksamheter. Detta skulle kunna vara en förebild för övriga lärosäten.

På högre nivå i utbildningssystemet (förutom i ren forskning) förekommer självklart en lång rad kurser mm med fokus på informationsteknik, men också specifikt inom ämnet hållbar/grön IKT. Här ges några få exempel.

Ett tydligt inslag av undervisning om hållbar IT i högskoleutbildning är den kurs som Uppsala universitet ger i ämnet "Grön IT i hållbar utveckling." Den belyser miljöperspektivet kring IT-användningen liksom social mjukvara som plattform för sociala interaktioner. Också vid Linköpings universitet förekommer flera utbildningslinjer där grön IT tas upp som ett moment.

Fler exempel finns runt om i landet. Exempelvis bedriver Göteborgs universitet särskild undervisning i ämnet. I en kandidatuppsats, Grön IT - Åtgärder för att bli ett miljövänligt företag ${ }^{135}$, visas att Grön IT är ett begrepp som har fått mer uppmärksamhet i Sverige de senaste åren, inte minst för att minska energiförbrukningen. Företagen anses inte ha kommit så långt än, och det finns fortfarande stora möjligheter att göra förbättringar, bl.a. genom att engagera personalen i miljöarbetet genom utbildning. Företagen kan då minska sin klimatpåverkan och sänka sina kostnader.

Inom utbildningssektorn, t.ex. inom skolan, finns inga tydliga styrdokument från politiskt och centralt håll när det gäller att påverka hur skolor och universitet bedriver sin verksamhet i riktning mot just "grön IT". Det svenska utbildningsväsendet har en stark självständighet, särskilt från gymnasienivå och uppåt. Det hindrar inte att grön eller hållbar IT ändå finns på flera håll i utbildningen.

135 http://gupea.ub.gu.se/handle/2077/23466 
Dessutom finns på flertalet stadier i skolväsendet undervisning i informationsteknik (IT), mer allmänt. IT/IKT kan i dessa sammanhang ses som ett indirekt verktyg för hållbarhet och grön tillväxt. Allmän ITkunskap i skolan behövs för att elever ska få digital kompetens - och detta i sig verkar gynnsamt för hållbarhet. Regeringen strävar allmänt efter att öka användningen av IT och digitala läromedel i skolan, och det finns flera enskilda satsningar genom åren, bl.a. i regi av Skolverket. Men samtidigt kan konstateras att ett stort antal läromedel fortfarande på gott och ont - har traditionell form, $\mathrm{d} v \mathrm{~s}$ trycksaker eller papperskopior.

Skolverket stödjer kreativ och kritisk IT-användning på olika sätt. Myndigheten erbjuder stöd och stimulans som syftar till att förskolor, skolor och vuxenutbildning ska kunna använda IT och media i undervisningen på ett genomtänkt sätt samt för att göra digitala lärresurser tillgängliga för skolan. Vissa insatser baseras på ett beslut av regeringen där Skolverket från 2009 har i uppdrag att främja användningen av informations- och kommunikationsteknik. Skolverket följer också upp barns, elevers och lärares IT-användning och IT-kompetens.

$K K$-stiftelsen har under några år genomfört attitydundersökningar om IT i skolan, där lärare, elever och skolledare i Sveriges grund- och gymnasieskolor intervjuas. Rapporterna visar att den pedagogiska nyttan av IT i skolarbetet upplevs som stor av flertalet lärare och att en bred majoritet av gymnasieeleverna upplever sig ha nytta av IT i skolarbetet. KK-stiftelsen arbetar också med IT i Lärarutbildningen där målet är att höja lärarstudenternas digitala kompetens så att de i sin kommande yrkesgärning kan använda IT för att stärka elevernas lärande och anpassa sina arbetsformer utifrån elevernas och samhällets behov. Det bör på sikt kunna stärka den ekonomiska utvecklingen på ett miljömässigt sunt sätt. 



\section{Avslutande tankar och reflektioner}

\subsection{IKT för grön tillväxt}

Det finns uppenbara fördelar för IKT-branschen i en värld med ändrat klimat och restriktioner i resande etc. med allt vad den "nya" tekniken kan bidra med och ersätta "gamla" vanor. IKT-sektorn, med de tjänster och tekniklösningar som erbjuds, är ett område som både anses i sig vara klimatsmart och som kan utveckla andra sektorer.

De områden som bidrar till den största delen av utsläpp av växthusgaser, energiproduktion och distribution, byggnader och transporter, är områden som de nordiska länderna alla arbetar med om än i varierande grad. Vi vet från tidigare studier att det genomförs många FoU-projekt inom dessa områden, såväl sådana projekt som behandlar attityder och beteenden som olika tillämpningsområden för IT/IKT. Det finns även exempel på samfinansierade forskningsprogram med flera nordiska länder som NORDITE där Tekes, VINNOVA och Norges forskningsråd finansierade $\mathrm{m}$ fl. Vad som däremot tycks saknas är etablerade bidragsprogram för tvärvetenskaplig forskning för IT och miljö.

Energi tycks vara ett område där nordiska länder både ligger långt framme och har mycket att bidra med när det handlar om förnyelsebar energi och energieffektivisering. Här kan IKT spela en betydelsefull roll på flera sätt, t.ex. i smarta elmätare. De ger miljömässiga fördelar då de automatiserar och ger fjärrstyrning av elektriska hushållsapparater samt tillhandahållande av realtids- och uppdelad information om energianvändning och priser. Smarta el-nät är en fråga som åtminstone diskuteras, men här ger intervjupersoner dock bilden att de nordiska länderna ännu inte riktigt är framme vid implementering.

När det gäller byggnader bedömer vi att det pågår aktiviteter kring byggandet av passiva hus och/eller funktioner inom byggnaderna som automatiskt reglerar och behovsstyr olika funktioner (även om genomslaget inte är så stort här ännu), energieffektiviseringar på olika sätt etc. Inbyggda system är integrerade halvledarkomponenter som möjliggör kontroll, mätning och ledning i en mängd olika användningsområden, däribland byggnader. I själva verket är huvuddelen av de halvledare som tillverkas idag inkluderade i icke-IT-produkter, t.ex. motorfordon, försvar, flyg och sjukvård.

Transporter är ytterligare ett område som är betydelsefullt ur miljöhänseende och som de nordiska länderna också har uppmärksammat i strategier, policys etc. Det handlar om både gods- och persontranspor- 
ter, bättre logistik såväl som ändrat beteende. Konkret kan det vara att ersätta tjänsteresor med exempelvis videokonferenser, byta ut fordonsparken till mer miljövänliga alternativ, ändra körbeteende, öka nätverkseffektiviteten etc. Tekniken för videokonferenser har funnits i flera år, men implementeringen har gått trögt. En miljövänligare fordonspark kräver utbyggd infrastruktur, t.ex. elbilar kräver tillgång till laddstolpar, och gasbilar kräver ett effektivt tillvaratagande av t.ex. matafall. Körbeteende försöker man förändra genom t.ex. trängselskatter etc, effekterna av sådana åtgärder tycks dock inte vara enkla att främja. Nätverkseffektiviteten i form av mer utbyggt och snabbare bredband står på de flesta nordiska länders agendor.

Nära kopplat till transporter är tillhandahållandet av varor. Ökad konsumtion av digitala varor avlastar också miljön och ger mindre utsläpp. Det kan röra sig om musik, litteratur eller tjänster istället för produkter, s.k. cloud computing. Cloud computing kan å ena sidan verka mer miljövänligt, dock kräver dessa stora datacenter stora mängder energi vilket ställer krav om förnyelsebara energikällor för att nettoeffekten ska vara positiv. I dagsläget finns också en rad hinder för utbredningen av Cloud computing, t.ex. juridiska konsekvenser av lagring av data och program tycks inte vara fullt ut utredda.

Digital ekonomi (d v s offentliga och privata tjänster via Internet) och elektronisk handel etc. förutsätter bred utbyggnad av bredband med hög överföringshastighet. Bredband är därför också en identifierat viktig fråga som sysselsätter alla de nordiska länderna.

Grön IT är ett koncept som är levande i Norden. Vid vår datainsamling visade det sig att Grön IT ofta står för fokus på direkta effekter av IT/IKT själva, snarare än användningen av I(K)T som en smart teknik att använda för att minska klimatförändringar och miljöförstöring.

Det ter sig som om företag kan se affärsmöjligheter i utveckling och försäljning av lösningar för exempelvis telekonferenser, kommunikation, andra distansarbetslösningar och teknik för smarta hus. Dock finns bedömare som menar att antalet företag som verkligen har gett sig in i det här nya affärsområdet - teknik för en hållbar utveckling - ännu är tämligen litet. Till viss del behövs ändrade ramverk och bestämmelser som gynnar företag som inriktar sig på denna typ av produkter och tjänster.

Det som också behövs är stöd för FoU och innovationer, både statlig och privat finansiering. Samhällsomställning kräver många olika lösningar vilket pekar på ett behov av sektorsövergripande samarbete och kunskapsutbyte hur IKT och smarta användningsområden kan ske resurseffektivt. I botten ligger att nya politiska avvägningar kan behöva göras.

IT/IKT bör i sig själv vara miljövänlig och energisnål, men om IT/IKT ska börjar leverera klimatsmarta lösningar i den omfattning som krävs och spela den roll som behövs för att vi ska leva mer uthålligt, behöver IT-branschen kunna få öka sin andel av utsläppen för att på så sätt få ner utsläppen totalt. Dessutom har IT-lösningar en stor fördel jämfört med många andra åtgärder eftersom de inte bara är bra för miljön utan också 
ökar produktiviteten, stöder innovationer, skapar nya smarta jobb och sparar pengar. För att tillvarata möjligheterna krävs att IT/IKT används på ett klokt och genomtänkt sätt. Även för detta krävs politiska, strukturella och individuella ansträngningar.

Utvecklingen drivs på av medierna, politiker, intresseorganisationer, företag och en allt mer miljömedveten allmänhet. Det som ofta pekas på $\mathrm{i}$ studier och expertutlåtanden är att vi i Norden för att försäkra oss om att bibehålla goda positioner dels måste främja forskning i högre grad inom IT/IKT dels att föra in IT/IKT som en naturlig del i undervisningen av barn och unga. Det sistnämnda, som fokuseras i nästa avsnitt, 7.2, är viktigt på lång sikt.

\subsection{Digital kompetens som grund i samhället}

Studier har visat att sociala aspekter av IT/IKT står på många av de nordiska ländernas agendor. En springande punkt i byggandet av ett hållbart samhälle med grön tillväxt är en hög grad av digital kompetens bland befolkningen. De nordiska länderna ligger globalt sett förhållandevis väl till. Digital kompetens är nödvändig i ett framtida samhälle och är mycket viktig redan idag. De nordiska länderna arbetar i olika grad för att öka den. Utbildning erbjuder en god möjlighet att utrusta de unga, den framtida arbetskraften, med goda förutsättningar att hantera ett digitalt samhälle. Även om utvecklingen går snabbt och många unga skaffar sina IT-kunskaper utanför klassrummet bedömer vi att skolan har mycket att tillföra i grundandet av digital kompetens t.ex. i form av att kunna hantera källor, källkritik, samt givetvis att locka till kunskapsinhämtning genom att använda I(K)T och digitala läromedel. Tillgången till hård- och mjukvara är en nödvändig förutsättning.

Vad är digital kompetens? Liksom när det gäller "grön tillväxt" varierar definitionerna och det tycks inte vara allmänt känt vad som avses. Detta kan givetvis innebära en svårighet för olika aktörer att veta vad det är som ska uppnås. Lärarna är en kategori av aktörer som till mångt och mycket tycks uppleva det svårt att integrera IT/IKT i undervisningen. Detta blir än mer angeläget att hjälpa denna yrkeskår med, då IT anses ha en positiv effekt på skolans övergripande mål och på elevernas prestationer. En högre grad av IT-användning borde dessutom kunna ge möjligheter till att individanpassa undervisningen efter olika elevers förutsättningar och behov. D v s kanske ge mer flexibla förutsättningar än vad som kan ges med traditionella läromedel.

Vad gäller IT-politiken krävs ett tänk som även innefattar utbildningsväsendet och sätter mer fokus på det. Strukturella faktorer, som utformningen av lärarutbildningen kan behöva ses över. Om inte lärarutbildningen arbetar med detta i tillräckligt hög grad utrustas inte blivande lärare på bästa sätt för att sedan i sin egen undervisning föra in IT/IKT på ett mer genomgripande sätt. Det krävs också att individerna, 
lärarna, utvecklar den IT-mognad och de kunskaper och färdigheter som de behöver för att använda IT/IKT i undervisningen. Det handlar dels om individens eget ansvar, men också om tillgången till fortlöpande vidareutbildning - eftersom utvecklingen på området informationsteknologi är mycket snabb. En fortlöpande anpassning av kunskaperna kräver flexibla lärare med vilja att ständigt utveckla sina färdigheter. För att stärka hela regionens utbildningssektor kan det finnas skäl till nordiska initiativ när det gäller kartläggningar och policyförslag rörande t.ex. lärarutbildningen.

Det tekniska kunnandet ges stor emfas i de nordiska länderna och ses som en nyckel till vidare utveckling av våra samhällen. Om Norden har ambitionen att bli (eller behålla sin position som) ledande inom IT är det helt nödvändigt att locka ungdomar att tycka att IT som både skolämne och praktisk verksamhet är intressant. Nordiska Ministerrådet kan ta initiativ till samordnande verksamhet och att sprida goda exempel.

\subsection{Förbättring av strukturer kan göras gemensamt}

De nationella näten (Forskningsnettet i Danmark, Funet i Finland, RHnet i Island, Uninett i Norge samt SUNET i Sverige) har, enligt bedömare, varit mycket viktiga för den gemensamma IT-utvecklingen för de nationella lärosätena samt för publika tjänster. NORDUnet bör därmed kunna spela en fortsatt betydande roll för IT-utvecklingen på nordisk nivå.

Då mycket av utvecklingen handlar om sådant som standardisering, interoperabilitet, data kompabilitet etc. ser vi behov av samarbeten mellan flera olika aktörer. Mot bakgrund av det borde nordiska initiativ (av exempelvis Ministerrådet) kunna tas emot väl.

För att exempelvis Cloud computing och en utvidgning härav ska fungera optimalt är interoperabilitet helt nödvändigt. D v s att kunderna ska undvika inlåsning vid byte mellan operatörer. Idag varierar detta utifrån olika tjänster och kundens egen kunskap. E-post är exempel på en tjänst som idag är standardiserad. Ännu återstår dock standardisering av dokumentformat, databasformat etc. som inte är interoperabilt idag. Datakompabilitet växer också i betydelse ju fler IT/IKT-tjänster vi konsumerar, d v s att kunder vid byte av leverantör inte tappar delar av sina data. Ett exempel är bokföringsdata som idag inte kan flyttas mellan leverantörer utan vidare utan att riskera dataförlust.

IKT driver priserna på kommunikation nedåt. Exempel som Skype visar att även den traditionella telefonin sjunker i pris. Många i ITbranschen tror på en framtid med många billiga eller (nästan) gratis tjänster som idag kostar pengar. I en övergångsperiod kan det dock finnas skäl att vara vaksam på att kompetensen fördelas någorlunda jämnt bland befolkningen. t.ex. avsaknad av bredband i Norden idag handlar inte om bristande tillgång utan om privatekonomiska hinder. Detta kan göra att vissa socio-ekonomiska grupper halkar efter. 
Norden anses idag ha goda innovationsmiljöer, gott utbildningsklimat etc. som gynnar en hög användning av IKT i samhället. Ändå finns arbete kvar att göra för att sprida användningen av IKT till flera i samhället och till flera olika områden. Finansiering tillsammans med kompetens kan vara faktorer som påverkar hur väl spridningen av smarta användningsområden för IKT lyckas. Kanske finns här behov av gemensamma nordiska insatser för att tillsammans driva utvecklingen i form av mer tvärvetenskaplig forskning, tvärsektoriella FoU-insatser, finansiering av spridningsprojekt etc.

Många barn och unga är idag redan tidigt IKT-konsumenter genom användningen av t.ex. smartphones och dataspel. Smartphones anses generellt komma att få en avsevärt viktigare position än stationära datorer och laptops i privatpersoners vardag. Även här är det, åtminstone i en övergångsperiod, en privatekonomisk fråga om individer är delaktiga i den utvecklingen eller ej.

Stora ekonomiska skillnader mellan sociala grupper spär ytterligare på den bild OECD målar upp med en klyfta mellan de som kan och de som inte kan nyttja modern teknik. Sett utifrån utbildning kan det slå allvarligt om vissa sociala grupper inte kan tillgodogöra sig undervisning och därmed få en sämre kunskapsinhämtning, vilket kan både i dag och i framtiden vara ett allvarligt hot mot samhällsutvecklingen. Ett väl fungerande utbildningssystem, och inte minst nordisk medverkan och gemensamma nordiska initiativ, är av stor betydelse.

Det blir mot den bakgrunden betydelsefullt med insatser kring undervisningens villkor, lärares kompetens, utbildningssystemens struktur och förmåga att inkludera alla elever och vara flexibla för att nå olika behov.

\subsection{Konsulternas avslutande ord}

Vi ser sammanfattningsvis följande punkter som viktiga att arbeta vidare med på gemensam nordisk nivå. Bl.a. bör kartläggningar och utredningar övervägas för att undersöka vad som mer konkret kan åstadkommas på nordisk nivå och hur detta ska ske i praktiken.

- Tvärsektoriella FoU-satsningar. Då tillämpningen av IKT ser olika ut inom olika branscher och sektorer, kan det finnas skäl att främja lärande mellan olika områden. Tvärsektoriella FoU-satsningar kan vara ett sätt att främja både lärande och innovativa lösningar. Befintliga nordiska organisationer kan driva detta arbete

- Tvärvetenskapliga forskningsprogram där IKT är inkluderat. Tydlig finansiering av forskningsprogram som inkluderar t.ex. miljö och IKT behövs för att utforska nya möjligheter och nya fördelar i användningen av IKT för ett bättre klimat och en hållbar utveckling. Ev. kan Nordforsk spela en roll här 
- Ev. kan även forskningsfinansiering behöva inriktas på att belysa effekterna av IKT på systemnivå. Det kan handla om förväntade och oväntade effekter av IKT:s bidrag till miljömål, hur det främjar förnybara energikällor, minskar transportvolymer, optimerar hushållsförbrukning av el etc.

- Standardisering, interoperabilitet, datakompabilitet etc. gagnas av att samarbete sker på nordisk nivå. Bl.a. kan NICe utnyttjas i ännu högre grad, som nordisk think tank och pådrivare. NICe har tidigare engagerat sig för ökad standardisering. De nordiska länderna ligger långt fram i IT-mognad och IKT-kunskap och kan därmed påverka och vara med och driva även den globala utvecklingen på området

- Öka den digitala kompetensen i hela Norden som en bas för grön tillväxt, genom gemensamma satsningar på information såväl som skol- och utbildningssamarbeten. Information från Nordiska Ministerrådet eller någon av dess institutioner kan spridas genom befintliga kanaler som Journal of Nordregio (till tjänstemän och forskare), Nordens Tidning $\mathrm{m}$ fl.

- Ge goda exempel och inspiration till lärare att arbeta mer med IKT. Här finns inspiration att finna från enskilda nordiska länder. Om olika officiella nordiska organ och/eller exempelvis Föreningen Norden eller liknande organisationer som finns representerade över hela Norden fick ett sådant uppdrag, skulle de kunna tjäna som tillhandahållare av seminarier, information etc. för att förmedla både goda exempel och kunnande på olika håll i de olika nordiska skolsystemen

- Olika nordiska organ som NiCe, NordForsk m.fl. kan ges uppdrag att öppna upp för kunskapsutbyte och samverkan genom att - i än högre grad än idag - rikta inbjudningar till seminarier på temat etc.

- Arrangera nordiska informationssatsningar, inom ramen för det nordiska IT-forum som är etablerat, som riktar sig mot företag och innovationssatsningar inom IT/IKT om grön tillväxt i syfte att samla diskussioner och skapa input till nordisk policy

- Kartläggningar och konkreta policyförslag rörande t.ex. lärarutbildningen kan bli resultatet av samordnade nordiska utredningsinitiativ. Det kan även handla om större fokus i olika stöd och mobilitetsprogram för att främja utbyte av kunskaper inom exempelvis IT-användning i undervisningen

Våra samhällen är beroende av IKT för att fungera, utvecklas och generera tillväxt - just därför är behovet av en väl genomtänkt och utformad I(K)T-politik stort. Inom IT/IKT-området går utvecklingen oerhört snabbt och ju mer input som kan införskaffas, t.ex. genom befintliga nordiska expertgruppen, desto större chans att få en träffsäker bild vid skapandet av gemensamma policys och satsningar. 